NBER WORKING PAPER SERIES

\title{
POLITICAL CONFLICT AND POWER-SHARING IN THE ORIGINS OF MODERN COLOMBIA
}

\author{
Sebastián Mazzuca \\ James A. Robinson \\ Working Paper 12099 \\ http://www.nber.org/papers/w12099
NATIONAL BUREAU OF ECONOMIC RESEARCH 1050 Massachusetts Avenue
Cambridge, MA 02138
March 2006

We have incurred many debts during our research on this project. Our greatest is to Malcolm Deas for many hours of patient and expert advice on the intricacies of Colombian political history. We would also like to thank Jorge Orlando Melo both for his ideas and suggestions and also for his practical help in undertaking our research at the Biblioteca Luis Angel Arango. We also received helpful suggestions from Ana-Maria Bejarano, Fern an Gonzalez, Salomon Kalmanovitz, Francisco Leal, Marco Palacios, Eduardo Posada-Carbo, Miguel Urrutia and seminar participants at Harvard and the CIAR group on Institutions, Organizations and Growth in Vancouver, particularly John Coatsworth, Jorge Dominguez, Roger Myerson and Torsten Persson and Guido Tabellini. The views expressed herein are those of the author(s) and do not necessarily reflect the views of the National Bureau of Economic Research.

(C2006 by Sebastián Mazzuca and James A. Robinson. All rights reserved. Short sections of text, not to exceed two paragraphs, may be quoted without explicit permission provided that full credit, including () notice, is given to the source. 
Political Conflict and Power-sharing in the Origins of Modern Colombia

Sebastián Mazzuca and James A. Robinson

NBER Working Paper No. 12099

March 2006

JEL No. D7

\section{$\underline{\text { ABSTRACT }}$}

In this paper we present historical evidence and a theoretical analysis of the origins of political stability and instability in Colombia for the period 1850-1950, and their relationship to political, particularly electoral, institutions. We show that the driving force behind institutional change over this period, specifically the move to proportional representation (PR), was the desire of the Conservative and Liberal parties to come up with a way of credibly dividing power to avoid civil war and conflict, a force intensified by the brutal conflict of the War of a Thousand days between 1899 and 1902. The problem with majoritarian electoral institutions was that they did not allocate power in a way which matched the support of the parties in the population, thus encouraging conflict. The strategic advantage of PR was that it avoided such under-representation. The parties however could not initially move to PR because it was not 'fraud proof' so instead, in 1905, adopted the 'incomplete vote' which simply allocated $2 / 3$ of the legislative seats to the winning party and $1 / 3$ to the loser. This formula brought peace. The switch to PR arose when the Liberals became confident that they could solve problems of fraud. But it only happened because they were able to exploit a division within the Conservatives. The switch also possibly reflected a concern with the rising support for socialism and the desire to divide power more broadly. Our findings shed new light on the origins of electoral systems and the nature of political conflict and its resolution.

\section{Sebastán L. Mazzuca \\ University of California at Berkeley \\ Department of Political Science \\ Berkeley, CA 94720 \\ smazzuca@berkeley.edu}

James A. Robinson

Harvard University

Department of Government

IQSS

1737 Cambridge Street

Cambridge, MA 02138

and NBER

jrobinson@gov.harvard.edu 
The complete exclusion of one party is a big mistake

Rafael Nuñez $(1885)^{1}$

The Liberal Party is tamed [...] It lacks energy for political struggle, and is satisfied with its portion of the spoils and its condition of minority force.

Alfonso López Pumarejo (1928)²

\section{Introduction}

Colombia has not always been a violent country. In fact, for the entire first half of the 20th century Colombia was one of the most peaceful countries in Latin America, standing out in the region as an exotic exemplar of a highly stable and competitive bipartisan democracy. When faced with the critical test for political stability in that epoch, which occurred when the continent was hit by the Great Depression in 1930, Colombia was the only big country in South America in which military interventions were not even considered. While an armed coup interrupted Argentina's until then steady path to democracy, and Getulio Vargas installed the first modern dictatorship in Brazil, Colombia celebrated elections as scheduled-moreover, the party in government, the Conservatives, lost the contest, did not make any move to cling to power, and calmly transferred it to the opposition.

However, Colombia was not born peaceful. That half a century of peaceful political existence was itself a major novelty in Colombian history. Colombia's 19th century was politically chaotic even by Hispanic American standards: the record includes nine national civil wars, dozens of local revolts, mutinies and pronunciamientos, material destruction equivalent to several years of economic output, and at least 250,000 deaths due to political violence.

${ }^{1}$ La reforma política en Colombia (Bogotá: Banco Popular, 1972), 122.

${ }^{2}$ Obras selectas (Bogotá: Cámara de Representantes, 1979), I: 58. 
How did Colombia make the transition from political chaos to political order? What were the causes of conflict before the turn of the century and what were the bases of internal peace after it? The emergence of order in Colombia is temporally correlated with a transformation in the political institutions shaping inter-party relations: internal pacification was concomitant with the introduction of special mechanisms for power-sharing between Liberals and Conservatives, Colombia's two dominant political forces. The central thesis of this paper is that the correlation between the emergence of order and the introduction of power-sharing institutions is not coincidental, but causal. Before 1905, institutions favoring power monopolization by a single party forced the opposition into revolutionary tactics and the government into violent repression, whereas starting in 1905 the emergence of institutions insuring both parties a share of political power roughly proportional to its electoral force allowed for a peaceful interaction between government and opposition. From the standpoint of power-sharing mechanisms, the key institutional change was the replacement in 1905 of majoritarian rule by the incomplete vote, a special kind of electoral system. Colombia in turn switched from the incomplete vote to proportional representation in 1929.

The emergence of political order in Colombia cannot be explained only by the introduction of power-sharing institutions. And power sharing institutions do not reduce themselves to the incomplete vote or proportional representation. Other causes of order and other mechanisms for power-sharing certainly exist. Nevertheless, power sharing was the main cause for the emergence of internal peace, and electoral rules were the only viable form of power-sharing in the Colombian context around the turn of the century.

This paper develops in six sections. The next section briefly reviews the transition from chaos to order, highlighting essential patterns of inter-party relations in post-independent Colombia. The third section offers a brief account of electoral rules, underlining differences between forms of representation that are necessary to understand what was at stake in the Colombian switch from one set of rules to the other. The fourth section provides an overview of Colombia's transition to proportional representation. It presents a comparative perspective of the two changes that marked the transition-the introduction of the incomplete vote in 1905 and of the quotient rule in 1929. Sections five and six present a 
detailed case study of the antecedents and dynamics of each piece of institutional reform. Section seven draws conclusions about political conflict, power sharing and representation in post-independent Colombia, placing our argument in relation to competing accounts in political science, as well as in Colombian historiography.

\section{From Chaos to Order: Changing and Enduring Po- litical Patterns}

Standard periodization divides Colombian political history between 1860 and 1930 into two blocks of time, known as Olimpo Radical (usually translated as the 'Radical Olympus' after Mount Olympus - where the Gods lived!) and Hegemonía Conservadora (Conservative hegemony), each of which is characterized by the dominance of one of the two parties and a different set of policies. During the Olimpo Radical, from 1860 to the early 1880s, the Liberals were in power. It was a period of frantic institutional reform, designed by the "Radical" faction of the party to eradicate Colombia's heavy colonial heritage. Prominent among these reforms were the most extreme version of federalism ever known in the Americas (allowing provincial armies and banning central intervention in inter-state conflicts), a frontal attack to the institutional and cultural power of the Church (massive expropriations of wealth, removal from education, and expulsion of the Jesuit order), and a number of free-market policies. The intended and unintended consequences of Radical Liberal reforms - especially the hostility of ample sectors in a deeply Catholic population and the increasing inability of the central government to stop centrifugal forces - provoked the Conservative reaction.

After a failed revolt in 1876-77, Conservatives formed a coalition with dissident Liberals, headed by "Independent" Rafael Núñez, that managed to displace Radical Liberals from power in the early 1880s. The Hegemonía Conservadora, sometimes also referred to as República Conservadora, was inaugurated in 1885 after Núñez's government crushed a revolution by Radical Liberals attempting to regain power. Conservative Hegemony lasted until 1930. During the subperiod known as La Regeneración (-1900), almost every component of the Radical experiment was reversed: power was recentralized, states lost 
their political autonomy, the authority of the president was reinforced and granted extraordinary powers, and the political, economic, and cultural position of the church was restored. Less spectacular were reversals in economic policy, which nevertheless included a significant increase in tariffs and new faculties by the government to intervene in the economy, especially the supply of money.

From another perspective, based not on party or policy distinctions, but on levels and kinds of political conflict, a different periodization for the 1850-1950 century can be drawn. The turning point for that periodization occurs around 1905, dividing the period into two blocks of time, the first marked by interparty warfare and the second one defined by peaceful power-sharing. This of course implies a subdivision of the Conservative Hegemony, viewed as a single period in the conventional periodization. In fact, if "hegemony" is defined in the technical sense of rule by one sector in society with the consent of the subordinate groups, only the second half of the Conservative Republic can be properly considered hegemonic. Before 1902 Conservative rule suffered quasi-permanent contestation by the Liberal opposition, which twice exploded into open military clashes - hardly a consensual government.

Parties were the main architects of the emergence of political order after 1905. But they had also been the main forces responsible for political chaos and material destruction before that date. Up until the beginning of the 20th century, both Liberals and Conservatives were partly electoral and partly military organizations, with proportions fluctuating over time. Military superiority was the key condition to access and keep government power. Although from 1860 to 1900 the vast majority of government changes followed constitutional prescriptions, the only two transfers of power from one party to the other occurred via military force (Mosquera's takeover in 1861, and Núñez repression of Radicals in 1885). Before 1905, then, party alternation in power was a rare phenomenon, and always a violent one.

Warfare was a pattern of inter-party relations, and as such it was a broader phenomenon than the two episodes of violent takeover by the opposition. It also included several failed revolutions, for instance, the 1876-77 war under the Radical Liberal government, and the 1895 war and the Thousand Days' War (1899-1902) under La Regeneración. Fur- 
thermore, as revealed during discrete periods of open war, party warfare also comprised continuing activities related to the preparation for repression by the government, and the organization of revolution by the opposition. When Radical Liberals were in power, for instance, private armies became a frequent phenomenon, whereas under La Regeneración a series of "diplomatic missions" to neighboring countries were dispatched by the Liberal party in order to collect weapons for the revolutionary arsenal.

The disappearance of warfare as a pattern of inter-party relations defines the passage from chaos to order. On the other hand, a pattern of party politics that persisted from one period to the other was the recurrence of internal divisions within parties, and the strategic utilization of splits by the rival. Faced with the division of the party in government into an official and a dissident faction, the opposition used to attempt a coalition with the dissident faction in order to displace the official faction from government. Instances of this pattern include the already mentioned alliance of the Independent or Nuñista faction of the Liberal party with the Conservatives in the early 1880s, flirtations throughout the 1890s between Liberalism and a moderate Conservative faction opposed to La Regeneración's policies, the "Republican Union" that won the presidential election of 1910, which was formed by factions from both parties that had opposed president Rafael Reyes (1905-09), and the election of Conservative José Vicente Concha for president in 1914, which counted on the support of the Liberal faction that had been left out of the Republican Union. A permanent feature of Colombian politics, bi-partisan alliances, however, changed from common military fronts to peaceful electoral coalitions in concomitance with the transition from chaos to order around 1905.

The main hypothesis of this paper is that the transition from chaos to order in Colombia, which involved the replacement of military fronts by electoral coalitions as the typical pattern of inter-party relations, was caused by a change of electoral system.

\section{$3 \quad$ What are electoral systems?}

Electoral systems are rules that convert popular votes into seats in legislatures - they translate electoral support for a party into institutional power. Electoral rules are usually 
classified by means of two polar types: proportional versus majoritarian representation. A perfectly proportional rule (PR) would assign a party a weight in Congress, measured in terms of the portion of seats under its control, that is exactly the same as the support it has among the electorate, measured as percentage of total votes received. Under perfect proportionality, for instance, a party that is voted for by $32 \%$ of the electorate would get $32 \%$ of the seats in Congress. On the other hand, the majoritarian extreme assigns all seats in Congress to the party that has earned the largest amount of votes, no matter whether it became the winner by getting $75 \%$ of the votes, $51 \%$ or $32 \%$. Majoritarian systems, thus, introduce a distortion between level of popular support and institutional power: for the winner of the electoral contest, they amplify in Congress its popular power, and they weaken (or even nullify) that of the rest of the parties.

In practice, extreme forms of proportional or majoritarian representation do not exist. PR, for instance, is usually combined with the use of "thresholds," that is, the requirement that parties must receive a minimum portion of votes (e.g., $2 \%$ or $5 \%$ ) in order to get representation. As parties below the threshold do not get any seats, parties above it get over-represented. Similarly, majoritarian representation is usually combined with the subdivision of the national political arena into a number of subnational "districts," each of which holds elections for choosing a fraction of the total number of seats in the legislatures. Even though each district uses a majoritarian rule and hence sends to congress only representatives from the winning party, the subdivision of a country into districts in practice prevents the existence of single-colored congresses, for different parties usually prevail in different districts.

The incomplete vote is a special kind of electoral rule. Like PR, it allocates seats in a single district to more than one party, generally the two largest ones. On the other hand, like majoritarian rule, it assigns a fixed portion of seats to the parties, which is defined beforehand (e.g., $3 / 4$ to the winner and $1 / 4$ to the runner up, or 2/3-1/3), irrespective of the amount of votes received by each force. That is, under the incomplete vote, what is at stake in the electoral contest is who the winner is and who the runner up is, but not the relative institutional power that they will have, which is established before the election. To distinguish it from majoritarian and proportional representation, the incomplete vote 
is sometimes referred to as a form of "minority representation," for it is the only one that insures that the minority in a district will obtain seats in Congress.

Electoral rules have obvious proximate effects on the distribution of institutional power among political parties, and that is the reason why, as Giovanni Sartori noted, party leaders invest so much time in Congress looking for support for their preferred rule. In general, parties that are small or expect to become small advocate proportional representation, whereas majoritarian rules are the option that best suits the interests of parties with $50 \%$ or more of the electoral support. ${ }^{3}$ Electoral rules are also considered to have important deep effects on the capacity of elected authorities to govern and political stability. According to a standard argument, in fact, positive proximate effects are associated with negative deep effects, and vice versa - the so-called trade-off between representativeness and governability. ${ }^{4}$ Majoritarian rules score low on representativeness because they tend to leave small parties with no seats in the legislatures, but they foster stability by inducing clear institutional majorities. Proportional rules favor the representation of different parties but, according to the argument, the frequent lack of clear majorities and the larger number of parties in Congress make coalition-formation and decision-making more difficult, potentially resulting in power vacuums. In the Colombian case, however, no trade-off between representativeness and governability existed during the period 1850-1950. In fact, as we will see, Colombia's stability after 1905 was achieved by making the political system more representative.

\section{The Colombian transition to PR: an overview}

The transition from majoritarian to proportional electoral institutions in Colombia involved two key reforms, separated from each other by almost a quarter century. In 1905 majoritarian rule was replaced by the incomplete vote, which established that the party

\footnotetext{
${ }^{3}$ Giovanni Sartori, Comparative Constitutional Engineering (New York: New York University Press, 1994), III.1.

${ }^{4}$ Arend Lijphardt, Democracy in Plural Societies: A Comparative Exploration (New Haven: Yale University Press, 1977), and Democracies: Patterns of Majoritarian and Consensus Government in Twenty-One Countries (New Haven: Yale University Press, 1984) are the locus classicus for this kind of argument.
} 
that won the elections would get $2 / 3$ of the seats, and the remaining $1 / 3$ would be allocated to the runner-up, irrespective of the specific percentages of votes. The incomplete vote was in turn replaced by the quotient rule, a standard version of PR, in 1929 - since then, with relatively minor adjustments and the exception of the National Front period, Colombian elections have relied on proportional representation.

Both the incomplete vote and the quotient rule were the visible results of an extended, albeit intermittent, negotiation process between the Conservative and Liberal parties. Both reforms were introduced while the Conservative Party was in power, during the second half of the Conservative Republic. Neither the introduction of the incomplete vote in 1905 nor its replacement by PR in 1929, however, fit the prevailing explanations of electoral reform, most of which are variations of Stein Rokkan's pioneering account of the Scandinavian cases. ${ }^{5}$ According to Rokkan, reforms to majoritarian rule occur when a Conservative Party in power anticipates that, with social modernization and the rise of Left parties, Conservatives would become a minority force and hence that their future position in the political arena would be better served by proportional representation than by majority rule.

In contrast to Rokkan's scenario of a retreating Conservative Party, both reforms in the Colombian transition to PR were introduced at a time when the Conservatives were expecting, correctly or mistakenly, that their dominant position would remain unchallenged well into the future. Furthermore, for both Colombian parties it was apparent that the Conservatives' share of legislative seats would be larger under majoritarian rule than under any alternative electoral institution, including the incomplete vote and the quotient. Hence, the electoral reform was meant to reduce, rather than enhance, the future institutional power of the party in government. As an additional contrast with Rokkan's depiction of the Scandinavian process, where electoral reform was a spontaneous and unilateral decision of the party in power, the incomplete vote the and quotient rule in Colombia were a concession made by the Conservative government to the Liberal opposition, which had advocated electoral reform for several years and was its direct

\footnotetext{
${ }^{5}$ Stein Rokkan, Citizens, Elections, Parties: Approaches to the Comparative Study of the Process of Development (Oslo: Universitetsforlaget, 1970), 150-157.
} 
beneficiary in terms of the consequent re-allocation of legislative seats.

If electoral reform in Colombia was the product of a negotiation between the Conservative government and the Liberal opposition, rather than an imposition by the former, and if it involved a reduction of the Conservative Party's power in Congress, the key question is: what did the Conservatives obtained in exchange for such concession? What motivated the Conservatives' acceptance of an electoral reform that would redistribute institutional positions in favor of their political rival?

It is in the specific terms of the Conservative-Liberal exchange where the 1905 reform and the 1929 reform differ. In 1905 the Conservative Party viewed electoral reform as a means to achieve political pacification: the incomplete vote would prevent military insurrections by the Liberals. Prior to 1905, the political exclusion of the opposition, as well as the disproportion between Liberal vote share and seat share caused by majoritarian institutions, had encouraged Liberals to pose an almost permanent threat of civil war. With the incomplete vote Conservatives agreed to increase the Liberal Party's share of legislative power from a fluctuating $0-5 \%$ to a fixed $33 \%$ of the seats, which in the Colombian bi-partisan context necessarily occurred at the expense of the Conservatives' own portion of power. Conservatives traded size for stability: they opted for a smaller but safer share of legislative seats. Increased minority representation in Congress would dissuade the Liberal opposition from insurrection.

In 1929, on the other hand, political stability was not at stake. Rather, a deep division within the Conservative Party around the party's candidates for the following presidential elections pushed the two internal factions to vie for the support of the Liberal opposition. Liberals made a transitory deal with a Conservative faction that, in exchange for electoral collaboration against the other faction, gave decisive legislative support to the introduction of the quotient rule. Hence, whereas in 1905 the vast majority of the Conservative leaders agreed to a reform of electoral rules out of fear of a continuation of political chaos, in 1929 only a faction of the Conservative Party supported electoral reform, and it did so in exchange for a short-term electoral benefit.

Although the incomplete vote was a hybrid electoral formula that became obsolete in the course of a couple of decades, its role in Colombia's political history has been 
substantially more important than proportional representation. The introduction of the incomplete vote was a true inflection point, one that closed the chapter of recurrent civil wars that had dominated the country since independence, and inaugurated a four-decade period of uninterrupted political stability. Under the incomplete vote, Liberals gave up rebellion and Conservatives stopped repression. In this sense, the incomplete vote was the pillar of the institutional environment that encouraged the development of the coffee industry and the modernization of the Colombian economy in the first half of the 20th century.

The introduction of proportional representation, on the other hand, involved significantly smaller proximate effects on the redistribution of political power, as well as smaller deep effects on political stability. In terms of the proximate effects, whereas the incomplete vote was meant to increase 10 times Liberals' representation in Congress, proportional representation was expected to carry a small positive adjustment in the Liberal share, from a fixed $1 / 3$ of the seats under the incomplete vote to an average of $35 \%$ or $40 \%$ under the quotient. That is, whereas the incomplete vote increased Liberals' institutional power by $1,000 \%$, the quotient was expected to do so by only $20 \%$. In terms of the deep effects, the stakes of the two reforms were dramatically different. The risks of political instability if the 1905 reform had failed would have been much higher, at least in the long run, than if the 1929 reform had failed. In 1905 leaders of both parties were remarkably aware that the continuation of majoritarian rule would have forced the Liberal party into "anti-system" tactics, whereas in 1929 Liberals were deriving enough power from prevailing institutions to completely discard the option of insurrection. Liberals were too satisfied with the incomplete vote for the Conservative Party to believe that they would engage in civil war if it was not replaced by proportional representation. The following two sections provide, in turn, an in-depth analysis of the antecedents, causes and effects of the 1905 and 1929 reforms. 


\section{The 1905 Reform: Incomplete Vote and Civil War}

\subsection{La Regeneración and its Rivals}

The 1905 reform had a crucial antecedent in a failed legislative proposal to establish "minority representation" in $1898 .{ }^{6}$ For a considerable number of politicians and observers of the time, the failure of the 1898 reform proposal had catastrophic consequences. In their view, reform would have prevented the Thousand Days' War. The legislative proposal was drafted by dissident Conservative representatives who feared that Liberals would rebel against La Regeneración unless they were secured a portion of institutional power that reflected at least part of their electoral force. The reform proposal seemed to have majority support in Congress, but both the President and the Senate vetoed it. The political process leading to the reform proposal, its blockage, and the subsequent political repercussions illustrate the intimate connection between disproportional distribution of power and civil war.

In post-Independence Colombia, governments of both political signs resorted to legal and illegal means to prevent the opposition from having a share of institutional power that was proportional to its levels of social support. Nevertheless, exclusion of the opposition reached an historical peak under La Regeneración. In effect, the 1880s witnessed two innovations, one in the composition of subnational executives and the other of national legislatures, that resulted in virtual monopolization of power by the Conservative party. The 1886 Constitution, the legal basis of La Regeneración, put a drastic end to more than two decades of hyper-federalism by introducing a unitary system of government that empowered the President to appoint governors in all states (renamed as departments). In practice, such legal innovation meant Conservative control of every subnational government, even in regions that were traditional bastions of Liberal support, like Santander.

\footnotetext{
${ }^{6}$ In the Age of the Olimpo Radical, states were empowered to choose their own electoral systems for selecting national and local legislators. All states adopted majoritarian representation, except for Tolima, which adopted the incomplete vote (provincial Constitutions of 1867, 1870 and 1877). That is the only antecedent prior to debates at the national level. However, in none of the debates reviewed in this paper was the Tolima antecedent referred to by the protagonists. The Tolima antecedent is nonetheless remarkable for its ground-breaking character. Apparently, the incomplete vote formula was invented by Condorcet, who included it in a Constitutional draft he proposed to the French Constitutional Convention of 1793 .
} 
Conservative re-centralization thus introduced a sharp contrast with prior Liberal administrations: before 1886 federalism had allowed for the reflection of local balances of power in the makeup of provincial governments, which in turn resulted in the control of several states - including a key state like Antioquia - by the opposition party.

During La Regeneración the participation of the Liberal party in Congress also became negligible. In contrast to the situation of the opposition party in prior decades, only two Liberal representatives occupied seats in Congress between 1886 and the outbreak of war in $1899 .{ }^{7}$ The drastic decrease of the Liberal presence in the legislature was in part an effect of reduced electoral support and the adoption of abstention as a de-legitimizing tactic. But it also reflected fraud, intimidation, repression and obstruction by the Conservative government, as well as the tighter official control over local politics and electoral boards made possible by re-centralization. To weaken the Liberal party's organization and obstruct its activities, La Regeneración relied on a key legal weapon, the Law number 61 of May 1888, known as the Ley de los Caballos (Law of the Horses), for its pretext was the decapitation of a few horses in Palmira (department of Cauca), which the government decided was a sign of a Liberal conspiracy. Coupled with a decree restricting the press issued a few months before, Law 61 granted the president extraordinary faculties beyond the control of the Congress and the courts: it allowed the Executive to unilaterally ban or repress political activities that the president himself considered "offensive of pubic order," a definition that conveniently provided ample leeway to neutralize the opposition. Deemed "subversive" by the government, a range of Liberal meetings and conventions were forbidden, several party leaders were sent to jail or exile, and there was almost no Liberal periodical that, at some point in time, was not suspended or shut down. The latter was particularly harmful to Liberals, as the press was the main instrument of intra-party communication and external propaganda. Hence, anemic legislative representation, coupled with exclusion from regional government and official persecution, narrowed Liberals'

\footnotetext{
${ }^{7}$ The first one, only elected in 1892, was Luis A. Robles, a representative from Medellín in Antioquia, perhaps the state where internal divisions within the Conservative camp were most serious. Rafael Uribe Uribe was elected in 1896, also from Antioquia (Sopetrán). A third Liberal politician, Santiago Pérez, was also elected to Congress in 1896 (from Santo Domingo in Antioquia) but he refused to take his seat in protest for alleged electoral fraud and manipulation in other districts.
} 
institutional power to minimal levels in Colombian history.

The politics of La Regeneración sparked opposition even within the files of the Conservative party. The Conservative schism can be traced back to a congressional debate in 1888 over a proposal to strengthen territorial centralization, but it intensified over the course of the following years, fueled by periodic disputes over nominations to the presidency and other political positions. Division became irreversible in 1896 when President Antonio Caro (1892-1898) revealed his intention to get re-elected. The Conservative party divided itself into a National block, which supported the government, and a dissident faction, the Históricos. As revealed in the writings of Carlos Martínez Silva, founder and top intellectual of the dissident movement, Históricos rejected official politics both on ideological and strategic grounds. For Martínez Silva, the suppression of the opposition's political rights not only was incompatible with the Conservative Party's foundational principles but also risked the breakdown of political order by forcing Liberals into revolutionary tactics.

Revolution was, in fact, the main option for many Liberals. But the Liberal party was also divided. Starting in 1896, however, the faction of the Pacifistas, mostly old leaders from the Radical period, gradually lost ground to the belligerent group, a younger generation of Liberal activists headed by Rafael Uribe Uribe. Both sectors shared the goal of dismantling the exclusionary structure of La Regeneración. However, whereas Pacifistas considered that a rebellion would be counterproductive given the military superiority of the government's forces and favored the strategy of forming an alliance with the Histórico block, Uribe Uribe and his followers viewed war and the threat of war as the only path to reform.

\subsection{8: Failed Reform and War}

It is against the backdrop of Liberal exclusion, Conservative dissension and danger of war that dissident Conservatives in Congress and the Senate took steps to reform the electoral law in 1898. In early August, Senator Carlos Calderón Reyes, and Representatives Eliseo Arbeláez and José Vicente Concha, who would become president in 1914-1918, presented separate proposals to introduce "minority representation" by means of the incomplete vote. Before joining the files of the Histórico faction, Calderón Reyes had served in the 
cabinet of Caro's government, and had authored the 1888 Electoral Code, which established majoritarian representation for all national and subnational Colombian elections (Law 7). Ten years later, Calderón considered that his code was "full of mistakes," and that not reforming it would be equivalent "to declaring that only the party in power has the right to vote [and to] consolidating a tyranny by scientific means." 8 Calderón described La Regeneración as a force transforming "a nation in which two parties have controlled the Government and exerted powerful influences" into a regime "in which only one of those parties has a voice and a place in the Parliament and the Assemblies, only one has a say in the big issues of the country [...] whereas the other one is completely excluded."9 "Peace can only be guaranteed," Calderón remarked, "with the reform of the electoral law." ${ }^{10}$ Defenders of the reform in Congress also drew a strong connection between power-sharing and peace. Arbeláez claimed that his project of electoral reform "responded to the burning need of pacifying the spirits." 11

The spirits that needed to be pacified belonged, of course, to Liberal politicians. Starting in 1891, every Liberal convention, program and manifesto demanded electoral reform, together with the abolition of the Law of the Horses. Liberals wanted electoral reform in order to obtain a greater share of institutional power. They systematically denounced fraud and exclusion from legislatures, but only rarely were they clear as to the specific remedies to those problems. When Historical Conservatives proposed the formula of the incomplete vote in 1898, Uribe Uribe led its defense as if the project had been designed by the Liberal party itself. In the process, he advanced one of the most brilliant statements for power-sharing in Colombia - and launched the strongest warning against La Regeneración. In his intervention of September 19, he stated that "Colombia's biggest problem is that of peace. This problem can only be solved in one way: by giving justice to the Liberal party. And that justice can only be achieved by approving the proposed reforms." 12

\footnotetext{
${ }^{8}$ Anales del Senado (AS) 1898: 105-106.

${ }^{9} A S$ 1898: 106.

${ }^{10} A S$ 1898: 105-106.

${ }^{11}$ Anales de la Cámara de Representantes (ACR) 1898: 313.

${ }^{12}$ ACR 1898: 386.
} 
Even though framed in terms of "political equality," Uribe Uribe's discourse made clear that, for Liberals, the main grievance under La Regeneración was exclusion from power. After asserting that "there is no equality before the law," he proceeded to list pieces of evidence of such inequality: "In thirteen years only two Liberal representatives went to Congress, in different terms; we have never had a seat in the Senate; by chance we have had two delegates in the legislatures of Antioquia and Panamá; when we have chosen officials for municipal councils, their terms were revoked by the President or the Governor of the Department; we have had nobody in the Ministries, in the Governorships, in the judicial branch or the electoral boards to protect and defend us." ${ }^{13}$ In Uribe Uribe's analysis, Liberal exclusion from power involved the breakdown of the underlying "political contract." Given that "the proportional influence in public affairs that should correspond to our party has been persistently denied," both Liberals and Conservatives should notice that "[t]he constitutional promise has not been fulfilled: the payment in rights in exchange for our obedience has not been delivered." 14

Political analysis was followed by military ultimatum:

I am not threatening or provoking. I am not coming here as the Roman consul before the Senate of Carthage, bringing in his uniform the options 'war or peace' for you to choose. I am just predicting the unavoidable. I am just warning that this, which today is a peaceful petition in favor of our rights, if you deny it, tomorrow will become a demand backed by the arms, and then, after costly sacrifices, one of two things will occur: if we win, we will give to ourselves not only what we are demanding today, or the full rights that belong to us, but even more than that, at your expense, because of the irresistible impetus given by victory; or, if we loose, not for that will our right die, and you will spend more resources in continuing oppressing us than those required to live with us in peace and equality [... G Give us the freedom to make public and defend our rights with the vote, the quill, and the lips; otherwise, nobody

\footnotetext{
${ }^{13}$ ACR 1898: 389.

${ }^{14}$ ACR 1898: 390.
} 
in the world will have enough power to silence the barrels of our rifles. ${ }^{15}$

Faced with the option of concession or war, National Conservatives would eventually risk war. But before it was too late to avoid the catastrophe, hopes of reform had temporally revived as Vice-president José Manuel Marroquín gave his explicit support to a new electoral law, and encouraged consideration of the proposals in Congress. Marroquín was in charge of the executive power because 84-year-old President Manuel Sanclemente had been granted a leave for health reasons. However, Marroquín's conciliatory attitude provoked a reaction by former president Caro, who urged Sanclemente to resume active presidential functions and restore the status quo ante. ${ }^{16}$ Sanclemente did shut the door to reform, instructing the Senate, where Nationals were a majority, to block the proposal. Before considering a new electoral law, Sanclemente remarked, "it would be better to wait for more peaceful times, so that an undisturbed study of experience and institutional options can suggest what is best for the public good." ${ }^{17}$ With remarkable political perception, Uribe Uribe had predicted in his defense of the reform that Nationals would allege inopportune times, in anticipation of which he claimed that "reforms are the cause of appeasement, so appeasement should not be taken as a precondition for reform." To demand "serenity" before solving the grievance is like "asking a doctor to wait until the disease is gone before providing the cure." ${ }^{18}$ With the return of Sanclemente and the interruption of the short-lived reform movement headed by Marroquín, the last hopes of reform vanished - and so did the chances of peace.

If Sanclemente's hostility to reform showed that bellicose Liberals were right in that $L a$ Regeneración would not transform itself from inside, war confirmed that Pacifista Liberals were right in that the Conservative government was too powerful to be defeated militarily. The Thousand Days' War (October 1898 - November 1902), the most destructive civil

\footnotetext{
${ }^{15}$ ACR 1898: 390 .

${ }^{16}$ Marroquín's reformism was clearly an unintended consequence of a careful gambit in "political paleontology," as contemporaries dubbed it, made by Caro in 1897. Caro's gambit consisted in forcing the nomination of 84-year-old Sanclemente for the presidency and 81-year-old Marroquín for the vicepresidency, with the expectation that their poor health or death would result in presidential power retuning to his hands.

${ }^{17}$ Monsalve Martínez, Manuel. Colombia, posesiones presidenciales, 1810-1954. (Bogotá; Editorial Iqueima, 1954). 310.

${ }^{18}$ ACR 1898: 387.
} 
war in 19th century Latin America, became a lost cause for the Liberals after the decisive defeat in the battle of Palonegro in May 1900. A coup by Historical Conservatives a few months after Palonegro succeeded in displacing Sanclemente from power and placing Marroquín in the presidency. However, Marroquín betrayed the Historicals' expectations of reform and pacification (in the same way that he had betrayed Nationals' plans in 1898 when he had to temporarily replace Sanclemente). To gain independence from the group that had sponsored his return to power, Marroquín relied on new political forces created in the course of the war aligned behind Arístides Fernández, a former doorman whose ferocious methods for capturing and repressing Liberals earned him rapid promotion through Conservative ranks. Proving in retrospect that his conciliatory policy towards the Liberal party in 1898 had been a purely tactical expedient, in 1900, as opposition forces were on the verge of disarticulation, Marroquín decided to inflict an irreversible defeat on Liberals.

\subsection{Negotiating Peace ... and Power-sharing}

Between Marroquín's coup in 1900 and the end of war, peace negotiations gave rise to a second (and final) antecedent of the 1905 reform. After the outbreak of war, and before the defeat at Palonegro, Liberals had suspended the demand for power-sharing and minority representation. A reason for that attitude certainly was that peace and the return to institutional life seemed too distant. But Liberals may also have remained silent on the issue of minority representation because the event of a military victory would return them to government, and once in power, it was not clear that Liberals would be willing to share power with the opposition. It was doubtful that Liberals in government would remain faithful to the principles they had embraced while in the opposition.

Almost immediately after the defeat at Palonegro, when Liberals realized that victory was practically impossible, Uribe Uribe dug up the banner of minority representation. Liberals began to signal that reform of electoral rules was the price they demanded for capitulation. Moreover, initial events surrounding Marroquín's coup encouraged Liberal's

hopes of electoral reform. For the ideologues of the coup, among whom Martínez Silva was prominent again, its raison d'etre was to end the war and to lay the basis of future 
peace by reinstalling the debate on electoral reform and Liberal participation in power. Marroquín's unexpected change of plans obviously cut off the latent agreement between Historical Conservative and Liberals, who nevertheless made several attempts to end the war under mutually satisfactory terms.

At the beginning of 1901 Uribe Uribe and Martínez Silva, leading figures of the new pacification efforts, initiated a series of contacts. In March Uribe Uribe traveled to New York, where Martínez Silva was sent by the government on a diplomatic mission, which most observers interpreted as an elegant form of exile. In a revealing communication, Uribe Uribe told Martínez Silva that "the war could have ended the minute after Marroquín took power, especially if one takes into account the common goals of the Liberal and the [Historical] Conservative parties, and the similar methods employed by one and the other [i.e., revolution and coup] in order to overthrow the National regime." Nonetheless, Uribe Uribe regretted, the government did not offer "an acceptable basis for an agreement with the Liberal chiefs." Marroquín only promised safe-conducts, and demanded "unconditional surrender, ignoring that Liberals form a political party with the right to be acknowledged as a social force and to receive proper representation." 19

Another year of attrition, which reduced the insurrection to intermittent guerrilla warfare out of the control of Liberal generals, made clear to all actors involved that the Liberal regular army had no option but capitulation. Still, Uribe Uribe and the other Liberal general, Benjamín Herrera - who had achieved impressive victories in Panamá but could not move his forces into the subcontinent - continued their efforts to extract political concessions from the government before signing a peace treaty. Liberals' proposals prior to the signature of the Tratado de Neerlandia (Treaty of Neerlandia) were shaped by the correspondence between Uribe Uribe and Colonel Carlos Adolfo Urueta, the emissary of the Liberal army before the government. Uribe Uribe instructed Urueta to request, as the condition for peace, the creation of an extraordinary Congress to treat constitutional reforms. Uribe Uribe also demanded a special mechanism for choosing the members of the Congress to insure Liberals that it was not going to be a "charade." Quoting a proposal he

\footnotetext{
${ }^{19}$ Otto Morales Benitez, Sanclemente, Marroquin, El Liberalismo y Panamá (Bogotá: Stamato editores, 1991).
} 
had made to Martínez Silva in New York, Uribe Uribe urged the government, via Urueta, "to accept that, out of the 64 seats in the Congress, 25 will be allocated to the Liberal party, which is a very modest demand." 20

In addition to providing further evidence that Liberals' main concern was participation in power, the communication to Urueta reveals that Uribe Uribe was perfectly aware of his weak bargaining position, and the associated lack of credibility of any promise that the government could extend. For him, Liberals should turn in their weapons after the congress met in order to guarantee the inclusion of Liberal representatives. But, he recognized, "it seems quite impossible to me that the Government will agree to this condition [i.e., a postponement of disarmament]." ${ }^{21}$ If Conservatives required military demobilization before making the promise of a special extraordinary congress with Liberal participation, then Liberals would be left with no tangible resources to sanction the Conservatives if they decided to renege on their promise. Hence, the very precondition of the government's promise (demobilization), made it non-credible. After meeting government delegates, Urueta informed Uribe Uribe that disarmament was in fact a precondition for signing any peace treaty. Moreover, after reviewing the situation of the Liberal army across the country, Urueta advised Uribe Uribe to give up hopes of concessions other than safe-conducts and reform promises. The Tratado de Neerlandia was finally drafted on October 24 and signed four days later. It had sixteen clauses: no. 1 and no. 3 defined the steps that the demobilization of the Liberal army should follow, and only no. 14 stated that "The Liberal emissary is confident that the President will follow through on his promise that the Liberal party will have fair representation in Municipal councils, Departmental assemblies, and the National Congress." ${ }^{22}$ A few weeks later Benjamín Herrera signed the Tratado de Wisconsin (the Treaty of Wisconsin, signed on board the U.S. battleship Wisconsin), which formally ended the war. The only political clause in the treaty included a nominal commitment by the Conservative government to encourage discussion of the proposals of electoral reform that had been submitted to the Congress

\footnotetext{
${ }^{20}$ Antecedentes del Tratado de Neerlandia 1902: 12.

${ }^{21}$ Antecedentes del Tratado de Neerlandia 1902: 13.

${ }^{22}$ Antecedentes del Tratado de Neerlandia 1902: 24.
} 
in 1898 (clause $7-B)$.

\subsection{Incomplete vote in 1905: innovation}

No politician in 1899 foresaw the devastating magnitude that the war would have. Events, duration and costs escaped the control of both Conservative and Liberal leaders. In the balance sheet, the column of intended consequences was only an infinitesimal fraction of the column of unintended ones. The "little skirmish of three months" that some in the government had predicted ended up lasting more than three years, causing more than 90,000 deaths and encouraging the separation of Panamá as an independent mini-republic. ${ }^{23}$ Lib- $^{-}$ eral leaders, in turn, powerlessly witnessed how their revolution degenerated into anarchic guerrilla and other politically futile impulses. Probably both Conservative and Liberal politicians would have changed their decisions on the eve of war if they had known that, by the end of $1903,4 \%$ of the male population would die, $7 \%$ of the territory would be lost, and the Colombian economy would suffer four years of paralysis in some regions, and massive destruction in others.

Especially after the loss of Panamá, preventing future wars became a top priority for political leaders of almost every affiliation. For the first time since the creation of parties, a broadly bipartisan consensus emerged by 1904. The consensus was built around the diagnosis of past ills and their remedies for the future. Intransigent elements from both parties finally seemed to converge to the vision of moderates, who insisted that the blame for past and recent chaos belonged to the vieja iniquidad (the "old iniquity"), Martínez Silva's celebrated formula to describe the persistent political exclusion of the opposition by the government. ${ }^{24}$ In the 1904 elections, with the support of moderate Conservatives and Liberals, General Rafael Reyes was chosen as president under the lemma "Peace and Concord." ${ }^{25}$ Soon after his possession, a stalemate with the Congress, chosen under Marroquín's presidential term, led Reyes to close it on December 14, eliminating in the process remaining intransigent Conservative elements from the political arena. Instead of

\footnotetext{
${ }^{23}$ See Jorge Orlando Melo, "La República Conservadora" in Ideología y Sociedad (Bogotá 1975).

${ }^{24}$ Revistas Políticas Publicadas en el Repertorio (Bogotá: Imprenta Nacional, 1934), 96.

${ }^{25}$ Historians disagree as to the role of fraud in this election, but they agree that he was the most popular candidate.
} 
calling another Congress, the new President decided to reform the Constitution and call a Constitutional Assembly, which would be inaugurated on March 15th 1905.

Anticipating future legislation on the matter, Reyes made sure that all political forces were represented in the Assembly. Each of the nine departments was to send three members, one from each Conservative faction, and the third one from the Liberal party. Most prominent Colombian politicians became members of the Assembly, including Victor Manuel Salazar, a Conservative general who had excelled at the war, future presidential candidate Alfredo Vázquez Cobo, the ubiquitous Uribe Uribe, and Herrera.

The assembly promptly applied the remedy prescribed in the post-war shared diagnosis: on April 13 a Constitutional Amendment introducing "minority representation" was passed. The legislative process was as fast as formal procedures allowed (four days), and the project received unanimous support. Bonifacio Vélez, Minister of Government and direct delegate of President Reyes before the Assembly, submitted the proposal of electoral reform on April 10th. The proposal's declared goal was to insure the representation of the opposition in the legislatures, but did not define the specific electoral rule to achieve it, which would be the issue of an ordinary law, complementary to the constitutional amendment. Article 4, the core of the project, stated that "in all popular elections that have the goal of forming public corporations [e.g., national and regional legislatures], the right of minorities to be represented is acknowledged, and the law will define the form and terms under which such representation will be carried out." ${ }^{26}$ That same day the project was approved by unanimity in "first debate," which according to Colombian legislative rules meant that representatives agreed to submit the proposal to a special commission in charge of studying it (according to the rules, the second debate is when modifications to the project, as suggested by the commission and the floor, are introduced, and the third and last round approves or rejects the final draft).

\footnotetext{
${ }^{26}$ Anales de la Asamblea Nacional $(A A N)$ 1905: 73. The Anales have an important typo. In the place where they should have published the draft of the law, instead of reproducing the draft, they mistakenly included the final version as approved three days later, which, very crucially, included the phrase "and the appointment of Senators" between the words "corporations" and "the right." The mistake is important because its introduction was precisely a modification to the original project by Reyes-Vélez suggested by a Liberal representative the day after the proposal was submitted (see below). We discovered the mistake by contrasting the Anales with the original actas of the session. The Anales are not faithful to the actas. For the actual acta, see Archivo del Congreso, Leyes autógrafas 1 a 21 de 1905, I: 70-74.
} 
On April 11th the commission, formed by Herrera (from Santander), Felipe Angulo (Bolívar), a former protégée of Núñez, and the Reyista Gerardo Pulecio (Cundinamarca), issued the report. Its first paragraph claimed that "this reform is the peace for the future; it is the first time national unity is formally proclaimed [...] for no Constitution since 1811 had had the courage to acknowledge the right of minorities to be represented; that was the cause of the countless civil wars that have scorched the country." 27 The commission also suggested to the body of representatives that no modifications to the project were necessary. The only voices heard that day were those of Liberal Representatives Juan Manrique (from Cundinamarca), who only praised the proposal, and José María Quijano Wallis (Cauca), who proposed a modification - a small but crucial addition to article 4, the "soul of the proposal." 28 After describing minority representation as "a guarantee for future peace in the Republic," Quijano noticed that article 4, by referring to bodies chosen in "popular elections," left out the selection process of the Senate, the members of which were not chosen popularly, but were indirectly appointed by departmental assemblies. Pulecio, the president of the commission, acknowledged the omission, implying that it was unintentional, and enthusiastically agreed to the modification. ${ }^{29}$ The new version of article 4, then, stated: "in all popular elections that have the goal of forming public corporations, and in the appointment of Senators, the right of minorities to be represented is acknowledged ..." All representatives gave their support to the modified version of the project. It became law the following day with unanimous approval, and was published on April 13th. The process was so swift, especially when compared to Colombia's own antecedents, that the President of the Assembly asked that a special mention to the "exemplary session" be put on the public record, emphasizing how "calm and composed the discussion was, even though the topic has been one of the most delicate and thorny

${ }^{27} A A N$ 1905: 73.

${ }^{28}$ Juan E. Manrique was a member of the Directorio of the Liberal party before the war. He was a Pacifist who tried various formulas, mostly electoral formulas, to prevent the war. On September 29th 1898 he signed a pact with President Marroquín to encourage electoral reform. Later on he complained about blockage by Sanclemente and the Senate. See El Nuevo Tiempo Jan 1903

${ }^{29} A A N$ 1905: 244-5. By showing the existence of this modification, we are rectifying the only other study of this amendment, due to Barbosa. Barbosa's otherwise complete review of the law suggests no modifications were introduced to the original project by Reyes-Vélez, and states that no interventions were made during the second debate. This is incorrect. At least three people participated in the second debate (Manrique, Quijano and Pulecio) and a non-trivial modification was made. 
issues for political parties in Colombia." 30

The constitutional amendment introduced minority representation as a principle, but did not define the specific electoral rule that would make the principle operative in practice. Two weeks after the amendment, by Law 42, the Legislative Assembly chose the incomplete vote. Article 33 of the law stated that two thirds of the seats in Congress and the Senate, as well as in regional legislatures and electoral boards, would correspond to the electoral majority, and the remaining third to the minority. ${ }^{31}$ The reform made every district have at least three representatives. For the computation of shares in districts where the number of seats at stake was not divisible by three, the Law required that such number be elevated to the next one that was divisible by three, and that the majority get $2 / 3$ of the new number minus 1 (e.g., in districts with 7 representatives, the two thirds were computed in relation to 9 , which, after the subtraction of one seat to the majority, left the opposition with 2 seats). The original draft of the law was again authored by Vélez. However, this time Vélez's proposal did undergo substantial modification before becoming law. Instead of the incomplete vote, article 26 in Vélez's proposal opted for a new demarcation of electoral districts that favored, "as much as possible, minority representation." 32 Each district would chose only one representative, but districts were supposed to be redefined so as to create some units in which Liberals were majority and hence could obtain the corresponding seat. The commission in charge of studying the draft - formed by J. S. Insignares S., named governor of Bolívar by Reyes, and Liberal Alejandro Pérez - discussed the proposal with the other members of the Assembly, and decided to eliminate article 26 and replaced it with the $2 / 3$ incomplete vote formula. The commission pointed out that single-member districts, if properly demarcated, may be in the interest of all parties, but they would actually "leave minorities within the district with no representation." The incomplete vote, on the other hand, would "insure and emphatically apply the republican principle of minority representation, as demanded by present circumstances." 33

\footnotetext{
${ }^{30} A A N$ 1905: 242.

${ }^{31} A A N$ 1905: 151.

${ }^{32}$ Archivo del Congreso, Leyes autógrafas 22 a 50 de 1905, II: 363.

${ }^{33}$ AAN 1905: 147, 148.
} 
The alteration of the Executive's original project by the commission, and the subsequent approval of the reformed version, reveals that Reyes did not have an automatic majority in the Assembly. Far from a rubber stump, the Assembly showed autonomy and determination to innovate. Less clear are the government's original intentions. Did the government proposal deliberately mean to temper concessions to the Liberal minority? Or was Vélez well-intentioned but he only ignored the proper "technology" to translate the principle of minority representation into operative rules for political practice? Although scarce, public records of the legislative process suggest a third option: Vélez was wellintentioned, and knew the alternatives, but he had sincerely believed that re-districting was the best option for achieving minority representation. Counterarguments by the Assembly may have changed his mind. The report of the commission, for instance, mentions that the introduction of the incomplete vote in the revised draft was "agreed upon with the Minister." ${ }^{34}$ Given the date of the commission's report (April 26), negotiations with the minister seemed to have been extraordinarily expeditious. Moreover, the same day the report was read, Vélez acknowledged the defects of his original proposal, arguing that "it left intact the hateful division of the Colombian family into winners and losers, which sooner or later will explode into bloody revolutions." 35 By contrast, the new legislative project would insure that "no more scandals will occur," and the commission should be "praised for its clever efforts" at reshaping it. ${ }^{36}$

\subsection{Incomplete vote in 1910 and 1916: ratification}

Reyes's government was overthrown five years after its inauguration, but minority representation as an institution survived and in fact became a permanent feature of Colombia's political system. Two critical indications of the level of consensus achieved by the incomplete vote as a power-sharing formula were produced in 1910 and 1916. In 1910 a Constitutional Assembly was convened to reform the constitution. Bi-partisan in composition, the assembly made the 1886 constitution more liberal. Crucially, it eliminated all the most important constitutional innovations of the Reyes's period except for minority

\footnotetext{
${ }^{34} A A N$ 1905: 147.

${ }^{35} A A N$ 1905: 149.

${ }^{36}$ AAN 1905: 150.
} 
representation. In 1916, a new electoral code was approved in order to systematize disperse pieces of electoral legislation into a single body of rules. It covered several fields, including the definition of citizenship, the organization of electoral justice, and the schedule for elections - regarding Colombia's electoral system, it ratified the incomplete vote. Therefore, in the context of broader institutional reforms, legislative bodies twice had the opportunity to change the electoral system in the 1910s, but on both occasions Liberals and Conservatives agreed to preserve minority representation. ${ }^{37}$

Reyes's fall and the constitutional reform of 1910 are closely connected events, for they were both the result of the rise of a new bipartisan coalition, the Republican Union. Republicanism grew mainly as a reaction against Reyes's dictatorial methods of rule, which included the closure of the Congress and the adoption of extraordinary executive powers. The Conservative leg of the new coalition was largely coterminous with the old Historical faction. The Liberal leg, in turn, was represented by politicians who had progressively removed their support to the government in response not only to authoritarian measures but also to the weakening of the Nationals, the reactionary faction within the Conservative camp. Once the threat from the Nationals vanished, Liberals who had initially supported Reyes out of fear of a restoration of the La Regeneración regime, decided to join the Republican opposition. Exceptions to the re-alignment of the Liberal elite included top collaborators of Reyes, most prominently Uribe Uribe and his followers. The main component of the Republicans' social base was the progressive business community of Antioquia, mainly landowners and bankers who resented Reyes's intervention in the economy and the cases of corruption derived from official contracts to build public infrastructure.

After forcing Reyes's resignation in June 1909, and winning the 1910 presidential election behind the candidacy of Carlos E. Restrepo, the Republican Union encouraged constitutional reform. ${ }^{38}$ Many of the authoritarian methods repudiated by the Republi-

\footnotetext{
${ }^{37}$ In 1909 Uribe Uribe presented a project for the systematization of electoral rules that also took for granted the incomplete vote was the best electoral rule.

${ }^{38}$ The triggering event of Reyes's fall was a new treaty to normalize relations with the US after its support to the independence of Panamá. The treaty provided Republicans an opportunity to mobilize opposition in March, led by Nicolás Esguerra in the Congress and a young Enrique Olaya Herrera, who organized the students' movement, in the streets.
} 
cans had acquired constitutional status during 1905-09 due to Reyes's practice of issuing executive decrees and submitting them to ratification by ad hoc constitutional assemblies. Republicans were determined to revise the changes by Reyes, but more generally the 1910 reform was meant to translate into constitutional norms the strong bipartisan consensus that had evolved since the end of the war on the need of strengthening the rule of law and the rights of the opposition. The reform reduced the power of the Executive and enhanced that of the Congress. Thus, presidential terms were shortened from six to four years, the Executive became accountable for all violations to the Constitution - not just the few specific cases foreseen by the 1886 text - and immediate reelection of the president was forbidden, whereas the Congress was assigned a chief role in the direction of foreign relations and the selection of members of the Supreme Court, and annual meetings of the legislatures were protected from presidential interference. ${ }^{39}$ Although these reforms involved important breaks in relation to the Reyes's regime, the key continuity was recorded at the level of the electoral rules.

During the second half of May, at least four separate projects concerning electoral rules were submitted to the constitutional assembly, including one by Nicolás Esguerra (May 15), the last survivor of the Radical Liberal period, founding figure of the Republican Union, and main architect of the constitutional reform. All four projects embraced minority representation as a general principle, and three of them specified the incomplete vote as the formula to make it operational in practice. The project enforcing only the general principle, presented by Conservative Hernando Holguin y Caro on May 20th, was discussed on May 26th and became law the following day. From the extraordinary pace of the legislative process it can be inferred that no significant opposition to the project was raised. ${ }^{40}$ As in 1905, the final version of the constitutional amendment left to ordinary law the determination of the specific electoral rule, but, in contrast to its predecessor, it mentioned possible operational formulas: "All elections in which more than two individuals are to be chosen will be ruled by the incomplete vote, the quotient rule, the cumulative

\footnotetext{
${ }^{39}$ Other important reforms were the abolition of the death penalty and restrictions on the issuing of paper money.

${ }^{40}$ There are no records of the debate, if it existed at all, so its characteristics must be deduced from its duration.
} 
vote, or any other mechanism that insures the proportional representation of the parties. The law will define the method to make this right effective." 41

The Republican Union proved to be a short-lived political force, but it left an enduring legacy in Colombian politics. Once the aspiration of constitutional reform was fulfilled, no shared goal was left for Conservatives and Liberals to remain united within a permanent coalition. Starting in 1914, with the election of José Vicente Concha as president, Colombia returned to the pattern of unambiguously Conservative governments. Nevertheless, the constitutional amendments of 1910 would last eight decades. Comparing the 1910 reform to the constitutions of 1863 and 1886, observers have noted that the key difference of the 1910 amendments, and the cause of their durability, is that they were consensually drafted by a bi-partisan assembly, expressing the institutional visions shared by all members of the political elite, whereas the two prior constitutions were actually the program of one party unilaterally imposed on the other after military victory. ${ }^{42}$ During the Republican period, however, the Congress failed to supply an electoral law specifying a method to put minority representation into effect. As a result, until 1916, the legislative vacuum was covered by the law that established the incomplete vote in 1905 (law 42/1905, art. 33).

In 1916, by Law 85, a comprehensive electoral code was adopted for the first time. ${ }^{43}$ Although the code was an extremely long text, with 307 articles and 17 chapters, it was essentially meant to achieve two broad goals: first, to establish a specific electoral rule, as required by the 1910 amendment; second, to strengthen controls over the electoral processes in order to reduce fraud and manipulation by local politicians. The project that was finally approved was originally authored by Bonifacio Vélez, Reyes's former minister and author of the 1905 constitutional amendment on minority representation. As a member of the National State Council in Concha's government, Vélez submitted

\footnotetext{
${ }^{41}$ Hernán Montoya, La Cédula y el Sufragio (Bogotá: Imprenta Nacional, 1938): 26.

${ }^{42}$ See Jorge Orlando Melo, "De Carlos E. Restrepo a Marco Fidel Suárez. Republicanismo y Gobiernos Conservadores," in Álvaro Tirado Mejía (ed.), Nueva Historia de Colombia (Bogotá: Planeta, 1989), 220-225, and Fernando Correa Uribe, Republicanismo y reforma constitucional, 1891-1910 (Medellín: Universidad de Antioquia, 1996), 7-10.

${ }^{43}$ An electoral law was sanctioned in 1888 , but it is not comparable with the 1916 Code in terms of scope.
} 
his project to the Senate in August 1915. It privileged the incomplete vote over the quotient rule because, Vélez alleged, it was a better mechanism for the representation of the minority. A colorful table, attached at the end of his project, backed his point. In the table Vélez's had computed how results for the 1915 legislative elections would have yielded different proportions of Liberal and Conservative seats under different electoral systems. The table showed that the incomplete vote granted Liberals five more seats than the quotient rule. ${ }^{44}$ Regarding the problem of fraud, the project included various dispositions, including one (art. 168/4) that declared invalid all elections "in which the number of votes issued is larger than the number of registered voters" - not at all an uncommon situation in Colombian electoral contests.

Vélez's draft had a long, and suggestive, genealogy. It was actually a counteroffer by the Government in response to an old demand by the Liberal party. Starting in 1911, Liberals had presented to the public a string of projects for an electoral code. The most important one had been authored by Uribe Uribe. The Conservative majority in the Senate rejected Uribe Uribe's project in 1913, but he insisted the following year. His assassination in October temporarily disbanded the movement in favor of a new code. In August 1915 Uribe Uribe's role in defense of a new code was taken on by Liberal Senators Luis de Greiff and Fabio Lozano. Uribe Uribe's original code placed a heavy emphasis on the reduction of fraud, and proposed the cédula, an individual identification card, as the main remedy for it. The cédula would be a certificate of the right of an individual to vote. It would replace in that function the lists of registered voters, the manipulation of which allowed officials in charge of voting places to arbitrarily exclude opposition voters or to make government supporters vote more than once in the same election. Uribe Uribe's project did not establish any new electoral rule, indicating his satisfaction with the system of the incomplete vote that was in effect.

The project by de Greiff and Lozano was very similar to that of Uribe Uribe in terms of the measures against fraud. For the electoral system, however, the 1915 Liberal project replaced the incomplete vote with the quotient rule. According to de Greiff, the incomplete vote was an eminently "unfair" mechanism because it resulted in a fixed proportion

\footnotetext{
${ }^{44}$ Vélez, Bonifacio. Proyecto de Ley sobre Reforma electoral (Bogotá: Imprenta Nacional, 1905), 69-70.
} 
of Conservative and Liberal seats irrespective of whether Conservatives "win by 16,000 votes to 4,000 or by 10,050 to 9,050." ${ }^{5}$ Nevertheless, the opinion of Liberals in the Senate was not uniform. Many opposition Senators, including Benjamín Herrera, still favored the incomplete vote, and de Greiff himself was open to compromise. The bipartisan commission in charge of studying his project, which included two Liberal Senators, Herrera and Rafael del Corral, rejected the quotient rule arguing that "given the current state of our political culture, it is not possible for it to work correctly." ${ }^{46}$ Over the course of the debate, Conservative Senators unanimously expressed themselves in favor of the incomplete vote. Some Conservative Senators simply embraced the status quo and rejected reform as a matter of principle. Dávila Florez, for instance, rejected innovation in electoral rules arguing that "If one makes jumps, there is no evolution. This is true both in economics and in politics." 47 Other Conservative Senators saw proportional representation as a system that was too complicated for Colombia's level of cultural and economic development. Exhibiting an affable degree political chicanery, a dialogue between Conservative Senator Benjamín Guerrero and his Liberal colleague Felipe Escobar illustrates this point:

Guerrero-There is too much ignorance among our rural villages to introduce proportional representation.

Escobar-Would you then sign a project of mandatory education with me?

Guerrero-No, because that would impose an unfair, even tyrannical requirement on the fathers of poor families. ${ }^{48}$

Ultimately, however, behind the concern with status quo and backwardness, Conservative Senators seemed to have feared that the quotient rule would induce divisions within their party, or the emergence of a competing third party, in relation to which the recent experience of the Republican Union could hardly be more suggestive. Guerrero himself described the quotient rule as the prelude to the emergence of "divisions" and "puny groups within the big parties." Guerrero urged his party fellows to reject the quotient rule

\footnotetext{
${ }^{45} A S$ 1915: 370.

${ }^{46} A S$ 1915: 355.

${ }^{47} A S$ 1915: 489.

${ }^{48} A S$ 1915: 475
} 
because "we have the inescapable obligation of reorganizing the Conservative union." 49 In the defense of his original project de Greiff had in fact attacked the incomplete vote as an obstacle to the development of third parties, although no evidence exists about a systematic plan by the Liberals to induce further divisions of their opponent. ${ }^{50}$ At any rate, Guerrero feared that was the case: "Liberal Senators may complain because we do not want to concede on the electoral innovation they advocate. But they must understand that we cannot accept the unacceptable [...] Liberals will laugh if we fall into their trap." 51 Faced with the opposition of all Conservatives and several fellow Liberals, de Greiff and Lozano promptly gave up on the quotient and accepted the incomplete vote. The motive behind the change of attitude was probably that, so long as Liberals had a share in power, de Greiff, like Uribe Uribe before him, was less concerned about changing the electoral rules than about reducing fraud. De Greiff did not want that the debate over electoral rules delayed or interfered with the approval of the rest of the project. Also, the legal vacuum opened by the 1910 amendment placed Liberals in an uncomfortable political situation. As representative Victor M. Salazar noted, "law 42 of 1905 has been tacitly abolished by amendment no. 3 of 1910; hence, the fact that since 1910 minorities have been granted the right to representation is due not to the fact that the right was guaranteed by any law, but to the fairness, sense of order, and benevolence of the Conservative Party." 52 Salazar's point was not technically right, for the National State Council had decreed that law no. 42 of 1905 would remain in force until a new electoral law was approved. On the other hand, a decree by the State Council did not have the same force as a national law, and Liberals were well aware of the difference. By the end of 1915, then, after brief consideration of an alternative electoral rule, both Liberal and Conservative Senators agreed to preserve the incomplete vote.

In the sessions of 1915, the Liberal project received much more attention than Vélez's code. In fact, the Liberal project was approved by the Senate and sent to the Congress in late September. Vélez's code, on the other hand, was not even submitted to be examined

\footnotetext{
${ }^{49} A S$ 1915: 474-475.

${ }^{50} A S$ 1915: 371.

${ }^{51} A S$ 1915: 475.

${ }^{52}$ ACR 1915: 854.
} 
by a commission in the Senate, the formal step before open debate. Although the Senate was dominated by a Conservative majority and Vélez's code probably expressed the official vision on electoral affairs, the approval of the Liberal project was not a surprising event: in the course of the debate, reforms were introduced to the Liberal code that made it perfectly palatable to the Conservative majority. The 1915 Congress, however, rejected the Liberal project. In fact, Congress' activity reached an irreversible stalemate in the first week of November. De Greiff's project would never be considered again. ${ }^{53}$ Disagreement, however, was not over electoral rules or the incomplete vote. Rather, it was instigated by conflict over the cédula and the provisions against fraud. For Conservative Carlos Jaramillo Isaza, the Senate's project was "retrogressive and absurd [...] In our population it is virtually impossible that people find the time to get their cédulas: what will happen with the rural workers, who cannot interrupt, not even for a second, their labor? [If the project was approved, then] a smaller number of people would go to vote." ${ }^{54}$ In what the Liberal minority considered an obstructionist move, Conservatives proposed to discuss Vélez's project instead of the one approved by the Senate.

In 1916, urged by the need to fill the legal vacuum opened by the 1910 amendment, the Liberal minority in the Senate assented to the proposal by the Conservative majority to revive Vélez's project and send it to the Congress. The code reflected the consensus on electoral rules, but it fell short of meeting Liberals' expectations about the reduction of fraud. For instance, Vélez's project had no cédula and its provisions against fraud, including the one canceling elections with more votes than voters, were a distillation of broader ideas already contained in the Uribe Uribe/de Greiff's project. After Vélez's project was easily approved in the Senate, the Conservative majority in Congress introduced heavy modifications to it, further weakening controls against fraud. Moreover, it returned the modified project for final approval to the Senate only a few days before the end of the annual sessions, virtually making a take-it-or-leave-it offer to Liberal senators. Senator Lozano, the co-author of the 1915 project, complained: "There has been a series

\footnotetext{
${ }^{53}$ See separate declarations signed by the Liberal minority and the Conservative majority on November 8th (ACR 1915: 715-717).

${ }^{54} A C R$ 1916: 853.
} 
of projects [of electoral code] since 1913, but all failed mostly due to negligence or obstruction in the Congress. This year we have accepted the one sent by the State Council [Vélez's one], which was modified and polished by a commission headed by [Conservative] Marceliano Arango. That is, we have accepted a project that was written and studied by bodies in which Conservatives had the majority. But a group of Conservative representatives in Congress fought against it, directly or indirectly. For weeks did [the project] sleep like a marmot. Later, they proposed modifications that distorted the thinking of the Senate, involving retrogression in the field of electoral legislation." 55 Particularly disturbing for Liberals was the discretionary power granted by the Congress's modifications to local electoral supervisors. The Congress's new project "allows electoral tribunals to set voting places in veredas [secondary rural villages]. That is, the Conservative majority is going to continue placing the voting places in the villages where Conservatives live and will avoid villages where the houses of the Liberals are located. [...] In election time, we will still have what is known as chocorazos in Magdalena, as canastadas in Boyacá and Cundinamarca, as and Milagros de Santa Isabel in Tolima [in italics, expressions for the illegal addition of ballots in favor of the government]." ${ }^{56}$ Even Conservative senators found the Congress's modifications questionable, but, as Pedro Molina argued, "there is no time to insist on the Senate's original project. We must not sacrifice the good in search of the perfect." 57 The Conservative criterion finally prevailed, and Vélez's modified project became law on December 31st.

To recapitulate, both the 1910 amendment and the 1916 electoral code ratified the incomplete vote. However, whereas the 1910 reform was promoted by a bipartisan coalition in a context of general conciliation between Conservatives and Liberals, the 1916 electoral code was introduced in the midst of a revival of inter-party conflict. Conflict, however, was not over electoral rules, but over fraud, which makes consensus over the incomplete vote all the more remarkable. In fact, on November 25th, the Congress approved art. 112 of the project, which established the incomplete vote, with no debate and as a part of a broader

\footnotetext{
${ }^{55} A C R$ 1916: 1117 .

${ }^{56}$ ACR 1916: 1117

${ }^{57} A S$ 1916: 1081
} 
package of tacitly agreed upon articles. ${ }^{58}$ Except for the brief exchange between de Greiff and the bi-partisan commission in the 1915 sessions of the Senate, the incomplete vote was always taken for granted as the fundamental focus of the underlying bipartisan consensus. The justification given by Vélez for the ratification of the incomplete vote could have very well been signed by any Liberal representative: "It is an undeniable fact, one that is acknowledged by our political history, that most of our civil wars, which flooded our soil with blood, paralyzed progress and broke the bonds of peace, have originated in the lack of properly representative Governments, in the systematic and hateful exclusion that was installed in the Republic. Minority representation prevents revolutionary attempts." 59 The fall of Reyes, the rise and disappearance of the Republican Union, and increasing political tension over fraud-four rather disruptive phenomena, which nevertheless did not threaten the incomplete vote at any moment, provided critical tests of the practically unanimous level of consensus achieved in favor of minority representation in Colombian politics.

\subsection{Causes of war and consequences of reform}

The historical events and processes reviewed above raise two questions for analysis. First, how is it possible to assess whether it was power-monopolization, rather than other factors, that was the cause of recurrent war in the second half of the 19th century, and powersharing the cause of peace during the first half of the 20th century? Second, why was the incomplete vote chosen over other forms of power-sharing, like proportional representation, bipartisan cabinets, fraud laws, or federalism? This section addresses the first question, whereas the next one answers the second one.

War before 1905, as well as peace after then, were certainly multi-causal phenomena. Historians and other social scientists have advanced both economic and political explanations. ${ }^{60}$ Explanations, however, are usually meant to account for a single, dis-

\footnotetext{
${ }^{58}$ Due to renumbering, the article on the incomplete vote in the final version of law holds the number 111.

${ }^{59}$ Vélez, Bonifacio. Op. cit., 62-63.

${ }^{60}$ For explanation of the first kind, see Charles Berquist, Coffee and Conflict in Colombia, 1886-1910 (Durham: Duke University Press, 1978), and for explanation of the second type see Helen Delpar, Red against Blue: the Liberal Party in Colombian politics, 1863-1899 (Tuscaloosa: University of Alabama
} 
crete event, like the Thousand Days' War, rather than the recurrent pattern of war, rebellion and repression in the 19th century, or the subsequent period of peaceful powersharing - let alone the macroscopic transformation of the Colombian political arena from chaos to order. Our explanation not only attempts to cover a big stretch of time, the 1850-1950 century, viewed as the juxtaposition of two broad political patterns, chaos and order. More importantly, it also emphasizes political causes at the expense of economic ones. However, in contrast to other political explanations, our argument is deliberately specific, for among the array of political factors that could be mentioned, it emphasizes power-sharing via electoral rules, and a particular legislative reform, the introduction of the incomplete vote in 1905. If pressed to argue by counterfactual reasoning, we would advance twin claims:

1. Wars in general could have been prevented, and the Thousand Days' War in particular could have been avoided, if the incomplete vote had been introduced in time.

2. Had the incomplete vote not been introduced in 1905, the pattern of interparty warfare would have revived a few years later.

Case studies are methodologically weak strategies of causal inference. However, three pieces of evidence provide support to the counterfactuals. First, at different points in time before 1905, Conservatives tried different packages of concessions to the opposition, but they never included the incomplete vote. In fact, except for electoral reform, by 1899 Sanclemente's government had removed all other political grievances Liberals had voiced, including the abolition of the Law of the Horses. Electoral reform was the only persistent Liberal demand that was not met. This is the reason why we favor a political explanation that is specific about the cause. As a posterior confirmation of the motivations driving Liberal rebellion, 1906 provides an instructive negative image of 1899: in 1899 Sanclemente put an end to extraordinary presidential powers but blocked electoral reform, whereas in 1906 Reyes granted reform but assumed dictatorial faculties. Sanclemente could not avoid civil war, whereas Reyes earned generalized Liberal applause. Evidence Press, 1981). 
on the terms of the exchange between Reyes and the Liberal party abounds. Even Herrera, who would eventually withdraw his support from Reyes's administration, considered that "after almost twenty five years of Conservative monopoly, Reyes allowed us to breathe, to get back into public life, to become citizens again." 61 A decade later, with the perspective provided by the passage of time, Liberal Senator Fabio Lozano and the Conservative costeño Manuel Dávila Florez engaged in a debate over a legislative project on "crimes against the Nation" in the context of which the do ut des of Reyes and the Liberal party was admitted with unusual political accuracy and candor. After Lozano attacked the project on the grounds that it would favor tyranny, Dávila Florez noted: "but Colombian Liberalism, your Honor, wholeheartedly supported General Reyes's dictatorship." Lozano quickly replied that "if your Honor wants, I am open to begin a dispute on this subject because I will be able to prove that Liberalism did not commit any crime in supporting that government. In order to neutralize any charges, it would be enough to consider that the attitude [of support] was a response to the very special circumstance that Reyes began his administration by offering Liberals a piece of sun, political equality." Dávila Florez would not miss the opportunity provided by his opponent's confession: "But that theory is shameful because it means that Liberalism accepts dictatorial governments in exchange for participation in power." 62

Second, whereas suspicion of fraud in presidential elections before 1905 was a quasiautomatic prelude to rebellion and armed conflict, after the introduction of the incomplete vote, Liberals' satisfaction with their portion of power outweighed their discontent with electoral manipulation by the Conservatives. In the 1922 presidential elections, fraud was blatant. ${ }^{63}$ But, in contrast to the pre-1905 antecedents, rebellion did not follow. According to our explanation, this was because Liberals had $1 / 3$ of the institutional power: after 1905, war became an option in which they had much more to loose, and much less to win.

The third line of empirical support to the counterfactuals is contained in the testimony

\footnotetext{
${ }^{61}$ Jorge Orlando Melo, Op. cit. (1989): 217.

${ }^{62} A S$ 1916: 558 .

${ }^{63}$ Isaías Chaves, Leopoldo Fergusson and James A. Robinson, "Ballot Stuffing: Theory and Evidence from the 1922 Colombian Presidential Election" (Unpublished, Department of Government, Harvard University, 2005).
} 
of the finest political analysts of the time, including Julio H. Palacio, Pedro J. Navarro, Luis Eduardo Nieto Caballero, and Hernán Montoya. All these personalities are widely recognized both for their political intelligence and their relative impartiality. For Palacio, for instance, the blockage of the 1898 proposal by the Senate and Sanclemente, "was the causa principalísma ['most principal' cause] of the devastating war." ${ }^{64}$ And vice-versa, "for me, the true father of peace in Colombia, a fact that the nation still needs to acknowledge and thank, is General Reyes, who facilitated minority representation. Without the dictatorship of Reyes, the peace treaties of Neerlandia and Wisconsin would have been dead letter for a long time, and another war would have liquidated the country." ${ }^{65}$ Navarro, in turn, confidently asserted that the incomplete vote was "the best law of Reyes's dictatorship: Colombia owes to it the internal peace that it has enjoyed for the last thirty three years [sic, writing in 1935], the basis of its progress and material wellbeing." Navarro added that peace had a second cause. "Even if it seems a paradox," peace was also caused by "the civil war of 1899-1902, in which Liberalism proved that it was willing to make any sacrifice in order to stop the violation of public liberties and citizenship rights." 66 Of course, Navarro's two causes were sequentially connected: peace was caused by the law, which in turn was caused by Liberalism's potential threat of new "sacrifices."

Regarding the role of economic factors, our vision, if stylized, is the opposite of Bergquist's. For this author, as for Marxists in general, economic forces provide the deep structure of the political process. Political decisions either reflect underlying economic interests, or are the effect of idiosyncratic and accidental factors. According to this perspective, political decisions are not consequential: they can at most "trigger" an outcome like a war, but those outcomes had nevertheless been determined beforehand by underlying economic processes. In apparent support of Bergquist's interpretation, the Thousand Days' War coincided with a fiscal crisis and a sharp decline in coffee prices, Colombia's main export. And Liberals did complain about economic policy. From our

\footnotetext{
${ }^{64}$ Historia de mi vida $(\mathrm{n} / \mathrm{d}): 249$.

${ }^{65}$ Ibid.: 290.

${ }^{66}$ Pedro Juan Navarro. El Parlamento en Pijamas (Bogotá: Talleres Mundo al Día, 1935): 15, 16. For a similar appraisal by Nieto Caballero, see Escritos Escogidos (Bogotá: Banco Popular, 1984), II: 266-267, and for Hernán Montoya's version, see La Cédula y el Sufragio (Bogotá: Imprenta Nacional, 1938): 17.
} 
perspective, however, economic factors can actually be seen as only the "triggering event" that unleashed a deeper political conflict around the historical exclusion of the opposition. As observers and participants of the events made clear, the fiscal crisis was endogenous to the political conflict over power sharing. Martínez Silva, Samper, and other participants aware of the "political economy" of La Regeneración, pointed out that most government spending was allocated to military contention and repression of the Liberals. ${ }^{67}$ Economic turmoil was actually a symptom of the impact of political conflict on the growing fiscal crisis, and the associated monetary expansion of the 1890s. Finally, Liberals' complaints against La Regeneración's monetary and fiscal policies can be seen as an opportunistic move to earn support from social sectors hurt by inflation, not the reflection of opposing economic interests (which Helen Delpar proved were not so different across political parties). Ultimately, the target of Liberalism was a share of institutional power.

\subsection{The Incomplete vote and Credible Power-sharing}

Why did Conservatives and Liberals agree on the incomplete vote as the main mechanism to share power? Other options of power sharing included laws against fraud, which would have enabled Liberals to get seats from districts that were their electoral bastions, or proportional representation, which could have also facilitated Liberal representation in Congress. Neither alternative, however, was a viable solution that would appease Liberals. Laws against fraud would not be viewed by Liberals as a real concession. "Changes in the law are useless unless customs change," Historical Conservative Martínez Silva observed in the midst of one of the recurrent debates on electoral corruption. ${ }^{68}$ He was expressing the opinion of a well-established current of thought, on which many Liberals and Conservatives converged, that blamed bad political habits or what was euphemistically called "lack of civic education." Perhaps more important, the key perpetrators of electoral fraud were local politicians, known as caciques and gamonales, in relation to whom national politicians had little or only intermittent control. ${ }^{69}$ The 1904 incident of electoral cor-

\footnotetext{
${ }^{67}$ Martínez Silva, Op. cit.: 467-68, 500-501. See also ACR 1898: 387.

${ }^{68}$ Revistas Políticas Publicadas en el Repertorio (Bogotá: Imprenta Nacional, 1934), II: 434.

${ }^{69}$ Malcolm Deas, "Algunas notas sobre la historia del caciquismo en Colombia", in Del Poder y la Gramática (Bogotá: Tercer Mundo Editores, 1993): 218-219 (first published in Revista de Occidente,
} 
ruption known as the Registro de Padilla, in which Conservative cacique from Guajira Juanito Iguarán persuaded other local authorities to sign a blank sheet so that he could fill in the "official" electoral results for the presidential election in his district, is only the most prominent one from a universe that probably included hundreds of cases. Either because of deep-rooted habits or the autonomy of electoral brokers at the municipal level, top leaders in the Conservative Party lacked the political resources needed to provide a formal solution to fraud that Liberals could find realistic.

Precisely because of fraud, proportional representation was not a viable formula for power sharing either. Faced with different options for electoral rules, Liberals probably feared that, with the problem of fraud still open, the installation of proportional representation would incite caciques to redouble their efforts at adulterating electoral results in order to minimize the presence of Liberals in the legislatures. In fact, in public discussions of alternative electoral rules during the Conservative Republic, a reason recurrently mentioned against proportional representation was "poor political culture," which sometimes meant that proportional representation required calculations that were too complex for the public, but more often it had the euphemistic sense of electoral corruption. ${ }^{70}$ In contrast to proportional representation, the incomplete vote is a "fraud-proof" formula. So long as the Liberal opposition obtained at least one vote, it would get $33 \%$ of the seats. The comparative advantage of the incomplete vote over proportional representation as a mechanism of power sharing in a context of moderate to high electoral corruption is what led Conservatives and Liberals to include the incomplete vote in the constitutional amendments of 1905 and 1910, as well as in the electoral code of 1916.

\subsection{The effects of the Incomplete Vote}

Redistribution of institutional power in favor of the Liberal party was the obvious proximate effect of the incomplete vote. However, political order, the deep effect, was the most important one. The Conservative party traded a portion of power in Congress in exchange for Liberal surrender of rebellious strategies. The new seats in Congress in turn gave Lib-

127, Madrid, 1973.)

${ }^{70}$ Evidence on this kind of argument will be reviewed below. 
eralism some influence in policy decisions. A prominent mechanism of Liberal influence in law-making relied upon divisions within the Conservative party, which compelled rival factions to compete for the support of the Liberal block, and extend concessions to their leaders.

The incomplete vote, however, had one negative, albeit transitory, effect for Liberals. Without violating the new electoral law, various local Conservative groups found a subterfuge to leave Liberals in their districts with no representation. The Conservative stratagem consisted in presenting two allegedly different lists and then coordinating the votes of their supporters so that one Conservative list obtained the portion the seats corresponding to the majority $(2 / 3)$, and the other Conservative list received the portion corresponding to the minority. This phenomenon, known as arrastre or listas corsarias, was not unusual, but it never become so pervasive as to threaten the basic principle of minority representation. In any case, the Law 13 of 1920, banned arrastre by specifying that parties, not lists, had to be represented in Congress.

\section{Towards Proportional Representation: Conserva- tive Dissension and Threat from Below in the 1920s}

The quotient rule, a standard form of proportional representation, was introduced in Colombia in November 1929. The reform was the outcome of a long and uninterrupted crusade by the Liberal party. Liberal support for proportional representation in the 1910s was restricted to a few isolated voices. However, it grew stronger over the first half of the 1920s, achieving perfect unanimity by 1925. Senator Luis de Greiff, the pioneering advocate of proportional representation in the early 1910s, was also the man responsible for aligning fellow Liberals into a compact block behind the advocacy of the quotient rule. From 1920 to 1929 Liberals submitted to the Senate and the Congress a dozen proposals to introduce proportional representation. Cosmetic variations of the same institutional innovation, the proposals reflected Liberals' various attempts at convincing a critical mass of Conservatives about the benefits of the quotient rule. In the Conservative camp, its representatives were uniformly opposed to innovation during the first half of the 1920s. 
In 1926-27, perhaps persuaded by the Liberal campaign, a number of them, still insufficient to force the reform, changed their mind and announced that they would accept the elimination of the incomplete vote in favor of a more proportional electoral system. In 1928-29, the Conservative party divided itself into two groups, each of which promoted a different presidential candidate for the 1930 elections. In return for Liberal support to their candidate, Alfredo Vásquez Cobo, the Vasquista group provided the necessary votes to pass the proposal of proportional representation - a transitory Conservative division allowed the decade-long Liberal campaign to eventually reach its goal.

Why did Liberals want to replace the incomplete vote with the quotient rule? And why did Conservatives resist reform? Liberals mounted a double attack against the incomplete vote, criticizing it both as a barrier against the entry of third parties - for it rewarded with seats only the winner and the runner-up - and as a distortion of the relative electoral power of Liberals and Conservatives - for the size of the rewards was fixed irrespective of the number of votes obtained by each party. "The main defect of the incomplete vote," de Greiff argued in support of his 1922 project, "is that it only recognizes two parties, one of which receives 66 percent of the seats and the other 33 percent, even if that proportion does not correspond to their electoral force." ${ }^{71}$ The barrier argument, in contrast to the distortion argument, involved a major break in relation to the kind of reasons that Liberals had traditionally advanced in order to promote electoral reform. In defending the participation of third parties, for the first time in the history of electoral reform Liberals favored an innovation that apparently had no benefits for them in terms of a bigger share of institutional power. According to Liberals, the third party to benefit the most from the hypothetical introduction of proportional representation would be the Socialists or another Left-wing force, which would subtract votes from Liberalism, not from Conservatism. Why, then, would Liberals advocate so resolutely, and Conservative resist so obstinately, the introduction of proportional representation? Three possibilities exist. The first possibility is that Liberals exaggerated the vitality of third parties, believing more in the distortion argument against the incomplete vote than in the barrier argument. In this case, Liberals might have actually favored proportional representation

\footnotetext{
${ }^{71}$ AS 1922: 203.
} 
because they expected that the number of seats they would gain by removing the $1 / 3$ ceiling imposed by the incomplete vote would be larger than the number of seats lost due to the division of the opposition between a Liberal and a Socialist party. On the other hand, Liberals might have genuinely believed that a Socialist party would emerge as a significant political force. In that case, they might have favored the quotient rule either because they viewed it as a mechanism to secure a public good shared by both traditional parties, like the prevention of a Socialist revolution (second possibility), or because they thought they could extract some exclusive benefit from a three-party system, for instance, the creation of a progressive Liberal-Socialist coalition that could force the government to make public policies more compatible with Liberal preferences (third possibility). The following three subsections explore, in turn, these possibilities.

\subsection{Demanding more than $33 \%$}

If the quotient rule was to enlarge the Liberal share of institutional power, the reasons why Liberals supported proportional representation and Conservatives opposed it would be self-evident. Liberals never admitted in public they were looking for a larger number of seats. Conservatives, in turn, insisted that, if they opposed proportional representation, it was not out of fear of a reduction of their weight in the Legislatures - on the contrary, they argued that it was to prevent more power falling into their own hands. In his opposition to the proposal of proportional representation that Liberals had submitted to the Congress in 1928, Conservative Vélez Calvo argued that "if the project becomes law, Liberals are going to complain after elections; scandals will be a thousand times bigger than they are today. It is obvious that in Nariño, in Antioquia, in Boyacá, and probably in Cundinamarca, in the Santanders, and in Huila, Liberalism will be reduced to its minimal expression. Probably Conservative exuberance in those Departments will not allow the opposition party to get any representatives, and we, Conservatives, do not have any interest to come to this house and fill it with $3 / 4$ or $4 / 5$ of the seats, instead of the $2 / 3$ we have had." Moreover, for Vélez Calvo, the quotient rule was a threat to public order precisely because it would eliminate the benefits that Liberals derived from the incomplete vote: "we are sure that, faced with total defeat under the 
new system, Liberals will for months talk about persecution, fraud, and oppression by the Conservatives. That will unsettle the country, with no benefits for anyone."72 An identical argument against proportional representation had been advanced by the report of the Conservative members of the commission that examined, and rejected, de Greiff's project in 1922. Signed by Senator Carlos Jaramillo Isaza, the report asked: "would it be good for the Republic that in the Department of Nariño, for instance, by virtue of the quotient rule, only members of one party [i.e., Conservatism] were elected? Is not it healthier for the country that a third of the seats belongs to the minority, no matter what the number of votes in its favor is?" For the report there were no doubts that the quotient rule would yield a larger representation for the Conservatives in the Senate and the Congress: "although this may seem an exaggeration to many, it has all the power of an axiom." 73 Even in October 1929, faced with the imminent approval of the quotient rule, Conservative Representative Guillermo Salamanca insisted on its negative effects for Liberalism, and made a last minute attempt to "save" his traditional opponents from the catastrophe: "if the quotient rule is approved, will Liberalism or any other Left-wing party be able to obtain the seat they have today in Departments like Boyacá? [...] We conservatives have fulfilled the duty of warning the Liberals about the danger that the quotient rule has for their organization." 74

\subsection{PR as a Public Good}

In the early 1920s, politicians of all persuasions recognized that the incomplete vote had been the basis of social peace for the prior fifteen years. However, social change over that same period made the incomplete vote obsolete as a mechanism of power-sharing - or so Liberals argued. Sustained economic growth during the two decades after the Thousand Days' War had in effect fostered urbanization, industrialization and the rise of a working class that, if still small, acquired political salience by organizing strikes, unions, confederations, and proto-parties, like the Socialist Party (whose first comprehensive program was issued in 1919). To persuade the government of the need of a new electoral reform,

\footnotetext{
${ }^{72}$ ACR 1928: 384 .

${ }^{73} A S$ 1922: 413.

${ }^{74}$ ACR 1929: 232.
} 
Liberals argued that sooner or later the incomplete vote, by marginalizing third parties, would push Labor-based parties like the Socialists into revolutionary tactics, in the same way that the majoritarian system had forced Liberals into civil war the previous century. This argument was, in fact, the most recurrent one in Liberal vindications of the quotient rule.

In the 1922 legislative debate around de Greiff's proposal, Senator Gómez argued that "social peace is not only affected by armed movements but mainly by an unfair law [i.e., the incomplete vote] that does not allow the representation of important currents of opinion $[\ldots]$ Given that the current law assumes that a party different from the historical ones does not exist, and given that such parties do exist, there are good reasons for many of our citizens to feel deprived of their political rights and be dissatisfied with the existing order." 75 Two years later, in the introduction of his own proposal of electoral reform, prominent Liberal Senator Galvis Galvis warned: "we have the obligation to prevent agitation, turmoil, and sacrifices. New trends are emerging that will cause serious frustration if not channeled properly by explicitly acknowledging their force and influence." ${ }^{76}$ In providing arithmetical examples of how the quotient rule would work, Galvis Galvis's tables included the Socialist Party as if it had become a permanent element of Colombia's party system. ${ }^{77}$ The argument recurred in the sessions of the following year, when for the first time the entire block of Liberal Senators signed a collective proposal on proportional representation, as a signal of how intensely committed they were to electoral reform. "It is imperative to modify the straitjacket imposed by the incomplete vote," declared the document. Proportional representation would "allow political, economic, and social parties to express themselves in their full force and induce them to work within the framework of the rule of law for the preservation of peace. Public order needs [reform]." ${ }^{78}$ In 1927,

\footnotetext{
${ }^{75}$ ACR 1922: 473 .

${ }^{76}$ AS 1924: 374.

${ }^{77} A S$ 1924: 374. It was Galvis Galvis, however, who was the pioneer in including Socialists in explanatory tables. His 1922 proposal, for instance, explained: "In a district with 14,000 voters, 10,000 of which are Liberals, 2,200 Conservatives, and 1,800 Socialists, in which 5 representatives are going to be chosen, under the incomplete vote, three would be Liberals and two Conservative; thus, 1,100 [Conservative] voters had the same electoral power as 3,300 [Liberal] voters, at the same time that while 1,100 voters can chose one representative, 1,800 cannot have any one." See $A S$ 1922: 203.

${ }^{78} A S$ 1925: 145.
} 
Liberal Senators again followed the tactics of signing a collective proposal, which this time was reinforced by a symmetric movement by the block of Liberal representatives in Congress. According to its declaration of motives, proportional representation "provides room for action to legions of Colombians who do not fit any more within old programs and the traditional party organizations." The rise of new parties "must be used in favor of the country. The current law [incomplete vote] is anachronistic and has already given to us all the good things it can provide." The block of Senators did not miss the opportunity to reiterate the catastrophic consequences that would follow if the Legislatures failed to introduce the quotient rule. If the political "currents that live underground and press to emerge to surface" do not receive participation in Congress, then "the Republic will last as much as the discontented masses want it to." 79 During the debate of the same proposal in the Congress, Liberal Carlos Hernández traced the trajectory of Colombia's electoral systems: "With the old system of absolute majorities only one party had representation. With the current system of the incomplete vote, two parties have representation. With the quotient rule, in the future all trends with enough force will have the door open to representation." 80 He added that if the Congress did not provide new electoral rules, third parties "will conquer the representation they have the right to either by the suffrage or by revolution. Tyranny or Revolution. These two extremes, which will be the death of the republic, are the outcomes we, the two traditional and big parties, must avoid as a common cause." 81 In 1928, Representative Gabriel Turbay, one of the most brilliant Liberal speakers and strategists, entered the debate only to provide new rhetoric for old concepts. He argued that, back in the 1910s, "the incomplete vote involved a big victory and progress, but it left the legacy of injustice, the abhorrent and arbitrary notion that only two parties can live [...] The coexistence of the two big collectivities is what gave birth to the system of repartimiento de prebendas [rent sharing], the inevitable outcome of the iron circle of Colombian Parliamentarianism." 82

Either as a dilatory maneuver or out of sincere conviction, a typical reaction by Con-

\footnotetext{
${ }^{79} A S$ 1927: 294.

${ }^{80}$ ACR 1927: 351.

${ }^{81}$ ACR 1927: 352, 353.

${ }^{82}$ ACR 1928: 378.
} 
servative leaders was to deny the existence or relevance of a third party, the raison d'etre of the Liberal campaign in favor of proportional representation. When, during the 1922 sessions, Liberal Senator Gómez asserted that it was time that the two traditional parties grant participation to Socialists, Conservative Jaramillo Isaza abruptly interrupted him: "but those parties do not exist, your Honor." Gómez replied: "Oh, please, do not shut your eyes in front of the evidence. Facts are not to be discussed, they can only be commented on." 83 More conciliatory and sophisticated, de Greiff conceded that only two parties were relevant at that time, "but we do not legislate only for the present. We also legislate for the future, and we have to make room to political groups that may later on find stable bases. Perhaps Socialists will strengthen their organization; it is also possible that a Labor Party is founded." Pushing the limits of imagination, de Greiff also speculated that "it may as well occur that an extreme faction of the Conservative party, reacting against the organization of the Socialists, forms a Fascist party." 84

A second kind of Conservative reaction against proportional representation pointed to the cultural backwardness of the milieu in which the new system was supposed to be introduced. For instance, the Conservative members of the commission that examined de Greiff's 1922 proposal argued that "to try to change the system in order to introduce a new one, which is hard to understand for the vast majority of Colombians, only for the sake of making an essay, is a danger for the Republic [...] We lack the necessary civic education." ${ }^{85}$ More concrete was Conservative Senator Pulecio, who argued that in rural villages only a few people could compute the votes using the quotient rule, because the officials in charge of voting places "are usually the head servants of the ranches [mayordomos de las haciendas], most of whom are illiterate." Without denying it, a Liberal Senator noticed that "Mr. Pulecio has actually raised the most serious charge against the policy of public education under the Conservative regime. To claim that in the municipalities no one can solve a simple division is the most formidable accusation that one

\footnotetext{
${ }^{83} A S$ 1922: 526 .

${ }^{84} A S$ 1922: 573 . The same spirit of anticipation and prevention was incorporated in the very text of a proposed law in the sessions of 1927 of the Senate. Article 1 of that project stated "In order to secure in a systematic way the proportional representation of all parties that might acquire [que vayan adquiriendo] political existence, elections will apply [...] the quotient rule." See AS 1927: 293.

${ }^{85} A S$ 1922: 412.
} 
can make against the generations educated by the Conservatives." 86 With this second reaction, Conservatives were advancing a diagnosis of Colombian society that was almost the exact opposite of the one that motivated Liberals to advocate reform. For Liberals, Colombian society, as reflected in economic development and the rise of new social groups, had advanced too much for the preservation of the incomplete vote to be a safe option; for Conservatives, society had advanced too little, as evidenced by the lack of cultural preparation for minimally complex political methods, for the introduction of the quotient rule not to risk instability.

\subsection{PR as a Private Good}

Faced with the rise of Labor-based parties, Liberals might have actually envisioned proportional representation as a mechanism to advance or protect partisan interests rather than as a public solution to potential political disorder. De Greiff, for instance, thought that the representation of Left-wing parties in the Legislatures could create an institutional ally to join the Liberals in a movement for progressive reforms. In a dispute with an ardent defender of the incomplete vote, de Greiff asked: "What fundamental innovation, in the area of public instruction for instance, can be attempted with the famous $33 \%$ equilibrium? Minorities have to restrict their focus to secondary laws: to vote laws on honors and pensions, because all substantial reform crashes against the force of the resistance imposed by the incomplete vote." ${ }^{87}$ If proportional representation became law, some of the new Socialist seats would probably be obtained at the expense of the Liberal party, but Liberals might nevertheless prefer reform if the aggregate weight of a Liberal-Socialist coalition surpassed the $1 / 3$ of seats that were allocated to them by the incomplete vote. That is, Liberals could have been willing to trade a reduction of the party's institutional power for increased chances of policy reforms.

Liberals might have also hoped that proportional representation would divide the Conservative party. Conservative divisions would favor policy reforms by forcing Conservative subgroups to compete for Liberal support in their preferred policy areas and hence to

\footnotetext{
${ }^{86} A S$ 1922: 574 .

${ }^{87} A S$ 1922: 574 .
} 
make concessions in other areas. Conservatives, not Liberals, acknowledged this potential transformation of Colombia's traditional two-party system. As Julio Eduardo Ramírez, member of the Valencista group, noted only weeks before the proportional representation became law in 1929, "[the quotient rule] is lethal for traditional parties, especially for the Conservatives, which is an organized party and its force stems from its discipline. The quotient formula opens the gate to all kinds of dissolvent forces and personal ambitions; it brings anarchy into elections; it weakens the cohesion that must exist within political groups, to the point that these - not too far in the future - may loose their own shape; finally, it fosters indiscipline and dissidence, atomizing opinion, leaving it without leaders and directors, essential factors in all parties." 88

A final reason why the Liberals might have wanted to eliminate the incomplete vote and replace it by proportional representation is that they feared that they would loose their position as first minority at the hands of Labor-based parties. As Rokkan argued, a majority party in decline wants to switch from majoritarian rule to proportional representation before the opposition becomes government. Similarly, a minority party that expects to be outcompeted by a new opposition force fights for the elimination of the incomplete vote in order not to disappear from the political arena. Although no evidence exists that Liberals held this expectation, some electoral results in the early 1920s were clearly favorable to Left-wing parties. For example, in the 1921 elections in Medellín, Liberals lost the minority seat to a third party for the first time since the implementation of the incomplete vote.

Liberals had a variety of reasons to support proportional representation, public or private - like the preservation of public order versus the search of a bigger portion of power-defensive or aggressive - the protection of its own minority position versus the quest for new coalitions capable of introducing progressive reforms. Naturally, not all reasons had the same weight in the minds of Liberal representatives or were equally prominent across legislative debates. For different Liberal politicians, at different points in time, some of those reasons seemed more relevant than others. For instance, whereas de Greiff in 1922 viewed proportional representation as a formula to improve his party's

\footnotetext{
${ }^{88}$ ACR 1929: 479.
} 
$33 \%$ quota, Turbay in 1928 thought that electoral reform would transform Colombia's party system to make it more compatible with the social cleavages of a mass society. Despite variations over time and across individuals in terms of the underlying justification, the aggregate result was the same throughout the 1920s: unanimous Liberal support to proportional representation. Unfortunately for Liberalism, no matter how uniform and strong their commitment to the quotient rule was, there was nothing they could do without the approval of the Conservative majority, or a fraction of it.

\subsection{The 1929 Juncture}

The unified resistance of Conservatism against proportional representation broke down in 1929. A year before, the Conservative party had divided itself around the two candidacies for the presidential election of 1930, those of Guillermo Valencia and Alfredo Vásquez Cobo. Vasquistas joined Liberalism in favoring the elimination of the incomplete vote and the introduction of a new electoral rule. In contrast to Liberalism's multifaceted justification of the quotient rule, however, Vasquistas' motivation was straightforward: they needed the votes of the Liberal party to secure the electoral victory of their own candidate. In exchange, they offered collaboration with a package of Liberal initiatives in Congress, including centrally the quotient rule. Vociferous opponents of proportional representation before 1927, like Jaramillo Isaza or Trujillo Gómez, suddenly became ardent defenders of reform. Some, like Senator Guerrero, who not too many sessions before had claimed that rural villages were too uneducated to understand proportional representation, and too poor to receive education, went as far as to allege a vast pedigree in favor of reform: "I am an advocate of the quotient rule, and I have presented projects establishing such principles since 1912." 89 The true motivation of the Vasquistas was publicly known, and Valencistas denounced it: "Our group will not risk, in return for short-term political gains, the integrity of the Conservative doctrine it advocates." 90 Valencismo's opposition, however, was powerless against the numerical superiority of the so-called "pliers" formed by the Liberal/Vasquista alliance. The original project was introduced by Liberal

\footnotetext{
${ }^{89} A S$ 1929: 486.

${ }^{90}$ ACR 1929: 479 .
} 
representative Guillermo Peñaranda Arendas, it was debated in the Congress between mid-September and early October and in the Senate in late October, and it became law on November 5th (Law 31).

To support their position in favor of proportional representation, Liberals and Vasquista Conservatives resorted to the same kind of "public good" argument that Liberals had advanced so many times in former sessions: economic change in previous decades had encouraged the emergence of new social groups, and new social groups, if not granted political representation, involve a threat of anti-democratic revolutionary movements. Naturally, Liberals did not mention their ambitions for a greater share of power, and Vasquistas omitted any reference to the electoral gains they expected to obtain from the alliance with the opposition. The novelty in the context of the 1929 sessions, however, was that Liberals and Vasquistas furnished the public good argument with a decidedly gloomy tone. Their discourses took for granted that an institutional crisis was an imminent fact. In the introduction to his project, for instance, Peñaranda Arenas asserted that "the problem [of political representation] has never been as acute as it is today. It is urgent to stop the discredit of the legislatures and the final ruin of republican institutions." 91 Trujillo Gómez, the Vasquista representative recently converted into the creed of proportional representation, similarly diagnosed that Colombian democracy suffered a "lethal illness" because "the voice of rural and industrial workers" and "the interests of professions and trades" have not been "heard in this Parliament." The incomplete vote is a "system that ignores the living forces from the suburbs, ranches, workshops, and factories," and for that reason it is to be blamed for the "twilight of democracy," which, among other "disturbing problems," includes "systematic abstention and popular fatigue with the electoral function." For Trujillo Gómez, proportional representation meant "the opportunity to stop this disaster: tomorrow it will be too late." 92 According to the opening statement in the report of the commission that studied the project in the Senate, "democracy suffers a regrettable bankruptcy due to the fact that the people have lost their faith in the electoral system." Like Liberals and Vasquistas in Congress, the commission in the Senate

\footnotetext{
${ }^{91} A C R$ 1929: 9.

92 ACR 1929: 214.
} 
predicted that proportional representation would "restore the lost trust and return the prestige to the Legislatures, reviving civic enthusiasm around electoral contests."93

Irrespective of whether advocates of proportional representation genuinely believed Colombia's democracy was about to break down, the tone in their statements clearly reflected the deep public impact of the first large-scale episode of class conflict in the country, the Masacre de las Bananeras, which had occurred almost exactly one year before in the fruit plantations of the Northern department of Magdalena. After a decade of political tension and ideological activation led by the Socialist Party, in October 1928 local plantation workers organized a strike against the United Fruit Company, the monopsonistic producer in the Caribbean. The official response was open repression. An indeterminate toll of deaths (seventy-five seems to be the most authoritative estimate) was one of the consequences of repression. The other consequence was the discredit of the Conservative regime, an outcome partly fueled by the rising Liberal politician Jorge Eliécer Gaitán, who unyieldingly attacked the government's approach to the bananeras problem from the floor of the Congress.

Two elements in the final version of the law provide a suggestive indication of the readiness with which Vasquista Conservatives extended extra concessions to Liberals. These elements make clear that, despite the rhetoric of crisis and catastrophe, Vasquistas' main concern was centered on the following presidential elections - and the purchase of Liberal support for their candidate. First, the form of proportional representation approved was not "pure" but "mixed:" a special clause in article no. 4 stated that under no circumstances could a party obtain more than $2 / 3$ of the seats (even if its vote share was larger than 66\%). By accepting this mixed formula, Vasquistas agreed to an arrangement that was bound to reduce Conservatism's legislative power. Second, in the course of the debate Vasquistas tolerated a surprising mico (monkey), which in Colombia's political culture refers to a piece of legislation that is inserted into the main project once it has reached a critical threshold of support by the legislators, and is presented as a minor modification to details of the law when it actually involves a major reform in areas that are not strictly related to the original spirit of the main proposal. The Liberal mico in

\footnotetext{
${ }^{93} A S$ 1929: 815 .
} 
1929 was no other than the cédula, the electoral identity card, which was surreptitiously introduced by Garbiel Turbay in the session of October 8th. Testing the limits of what Vasquistas were willing to concede, Turbay's mico has been celebrated by the Liberal party as one of the most skillful legislative moves under the Conservative Hegemony.

Like the incomplete vote in 1905, the introduction of proportional representation in 1929 was a concession by the Conservative government to the Liberal opposition. In contrast to the 1905 reform, in return for which Conservatives secured political peace in the long term, the 1929 reform was expected to provide a short-term political gain for a faction of the party in power. Although different Liberals politicians favored proportional representation for different reasons, Vasquista Conservatives had one motivation for the approval of a new electoral reform, namely, to obtain Liberal support for the presidential candidacy of Vásquez Cobo. The electoral motivation, which the rival faction of the party did not hesitate to condemn, was naturally hidden behind the rhetorical invocation to higher goals, including the incorporation of the incipient working class into the institutional arena as a third party (a goal that some Liberals apparently did embrace). As a measure of the price that Vasquista Conservatives were willing to pay for Liberal support in the following presidential elections, they agreed not only to proportional representation but also to the cédula, a venerable demand by the opposition, and a legal ceiling on the amount of seats that the government could get.

\section{Conclusions}

The transition from chaos to order in Colombia in the mid 1900s was driven by a change in the institutional allocation of political power. After the Thousand Days' War, Colombia's two parties agreed to share power by means of a new set of electoral rules. The incomplete vote, the cornerstone of the new electoral rules, was a strategic concession by the Conservative government to the Liberal opposition. In exchange for permanent representation in the legislatures, Liberals abandoned military insurrection as a political strategy. Transition to proportional representation was completed in 1929 with the introduction of the quotient rule. The quotient rule was also a concession from the government. This new 
concession, however, was not driven by Liberalism's potential military power but by the institutional power it had accumulated since the first concession. The incomplete vote provided Liberalism with political resources to press for more political resources. The opportunity to seize new resources arrived when, in the eve of the presidential election of 1930, the Conservative party split, and rival factions started to bid for Liberal support. Political peace was not at stake in 1929-at least, Liberals were too satisfied with the status quo to challenge it.

Findings on the transition from majoritarian rule to proportional representation in Colombia are relevant both for the study of electoral history in Colombian Historiography, and the study of electoral institutions in Political Science.

Recent historiography has underscored the existence of what Eduardo Posada-Carbó has called an "electoral tradition" in Colombia, which can allegedly be traced back to the independence period. ${ }^{94}$ According to this argument, Colombia's electoral tradition manifests itself in the energy that politicians of both parties have traditionally invested in elections, including campaigns adapted to different audiences, the early appearance of political newspapers, and in general a permanent interest in gaining the electoral favor of an increasing number of sectors in society. For Posada-Carbó, a key feature of Colombia's electoral tradition would be the competitive nature of electoral contests, that is, the fact that in general election results were uncertain, that winners in some cases were decided by close margins, and that a number of government-backed candidates actually lost the race. Our research on the transition to proportional representation in Colombia shows that elections were not the only arena in which politicians competed for political power. The allocation of political power in Colombia was also decided in ongoing negotiations about the rules that defined how votes would translate into seats. Moreover, in the 1910s and 1920s leaders of both parties invested extraordinary amounts of time and effort in the design and debate of the institutions governing elections. Throughout those two decades, no other issue received more attention in the Congress or the Senate. Specialists in elec-

\footnotetext{
${ }^{94}$ Eduardo Posada-Carbó, "Limits of power: elections under the conservative hegemony in Colombia, 1886-1930", in Hispanic American Historical Review, 1997, 77, 2: 245-280, and "La tradición electoral" (manuscript, 2005).
} 
toral rules included not only second level politicians of both parties, but also top leaders like Uribe Uribe, who drafted a proposal for the first systematic electoral code, Abadía Méndez and Olaya Herrera, the intervention of whom was crucial for the approval of the law eliminating the pirate lists in 1920, or José Vicente Concha, the author of a handbook in constitutional law that contained the most up to date discussion of alternative electoral rules. In the legislatures, debates around electoral rules reached peaks of sophistication when, for example, Liberal de Greiff displayed complicated arithmetical computations to illustrate how different combinations of electoral rules would work. The legislative debate naturally extended into the media, but it also reached academia. Before 1930, at least nineteen doctoral theses were written on the topic of proportional versus majoritarian representation. Concha and Olaya Herrera were regular members in the committees of that kind of dissertation. Hence, to complement and reinforce the recent argument about Colombia's electoral tradition, both elections and debates around the rules governing elections were vibrant political arenas. And they both mattered for the distribution of political power between Conservatives and Liberals.

Regarding the other element of the electoral tradition reviewed by Posada-Carbó, the competitive nature of elections, it is worth noting that, according to our research, the transitions from order to chaos occurred in concomitance with the rise of a mechanism that made electoral contests for legislative seats less competitive. In effect, by defining beforehand a fixed portion of institutional power for each party, the incomplete vote removed a key element of uncertainty inherent in most electoral contests. Throughout the 1910s and 1920s, Conservatives and Liberals took for granted the two thirds/one third division of the political pie. And, according to our argument, it was precisely that noncompetitive mechanism that made possible the primacy of civilized political interactions over armed conflict. Elections became relevant in Colombia only when they lost their competitive nature.

Our research on the transition from majoritarian rule to proportional representation in Colombia can also be located within broader debates in Political Science on the origins of different types of electoral rule. The Colombian case illustrates that Stein Rokkan's argument was right in that parties choose electoral rules to maximize their share of seats 
in Congress. However, our research also points to an important caveat: parties maximize institutional power subject to the constraint that political order is preserved, which is done by securing that the rival parties receive a share of political power sufficient to dissuade them from anti-system tactics. The incomplete vote is not the only form of power-sharing, but it was especially suited for the Colombian case, which had eliminated federalism (and hence the possibility that the opposition controlled subnational executives), and had a long tradition of de-centralized electoral corruption (which reduced the viability of proportional representation as a form of power sharing in the national legislatures).

The reform of 1929 introducing proportional representation illustrates a subtle point about the considerations involved in the choice of electoral rules. There normally exists an amount of institutional power, in this case, a number of seats in Congress, that is subject to "normal" political transactions. Those seats can be thought of as the arithmetical difference between, on the one hand, perfect proportional representation, under which the portion of seats in Congress is identical to the electoral weight of each party, and, on the other hand, the amount of seats needed to satisfy the "no-revolution constraint," that is, the number of seats that just dissuades the opposition from adopting a belligerent strategy. In other words, any seats that are conceded to the opposition in addition to those that satisfy the no-revolution constraint, have to be understood not as part of the price that the government is paying for peace, but as belonging to a regular political exchange, potentially involving short-term electoral gains. Whereas the 1905 reform secured peace for a 50-year period in Colombia, the 1929 reform was meant to achieve a much more modest and partial goal, the victory of one Conservative faction in the 1930 presidential election (and, despite the price paid, none of the Conservative candidates won the election). 